\title{
Pacific Northwest Laboratory Annual Report for 1990 to the Assistant Secretary for Environment, Safety, and Health
}

Part 5: Environment, Safety, Health, and Quality Assurance May 1991

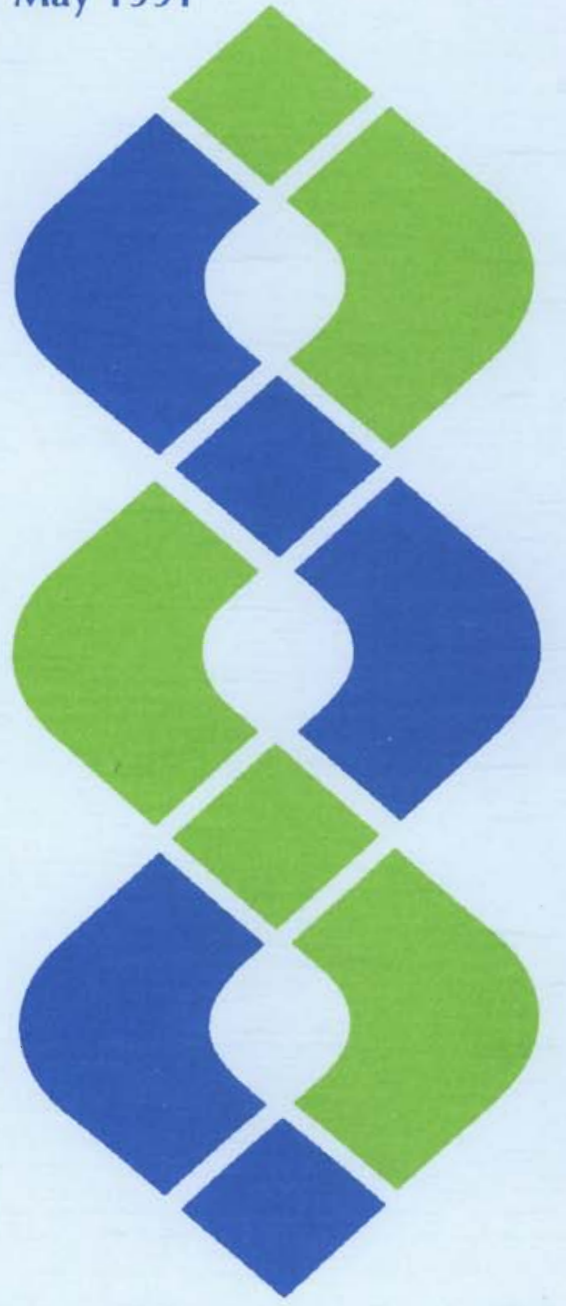

Prepared for the U.S. Department of Energy under Contract DE-AC06-76RLO 1830

Pacific Northwest Laboratory Operated by Battelle Memorial Institute for the U.S. Department of Energy 


\title{
DISCLAIMER
}

This report was prepared as an account of work sponsored by an agency of the United States Government. Neither the United States Government nor any agency thereof, nor Battelle Memorial Institute, nor any of their employees, makes any warranty, expressed or implied, or assumes any legal liability or responsibility for the accuracy, completeness, or usefulness of any information, apparatus, product, or process disclosed, or represents that its use would not infringe privately owned rights. Reference herein to any specific commercial product, process, or service by trade name, trademark, manufacturer, or otherwise does not necessarily constitute or imply its endorsement, recommendation, or favoring by the United States Government or any agency thereof, or Battelle Memorial Institute. The views and opinions of authors expressed herein do not necessarily state or reflect those of the United States Government or any agency thereof.

\author{
PACIFIC NORTHWEST LABORATORY \\ operated by \\ BATTELLE MEMORIAL INSTITUTE \\ for the \\ UNITED STATES DEPARTMENT OF ENERGY \\ under Contract DE-AC06-76RLO 1830
}

Printed in the United States of America

Available to DOE and DOE contractors from the

Office of Scientific and Technical Information, P.O. Box 62, Oak Ridge, TN 37831; prices available from (615) 576-8401. FTS 626-8401.

Available to the public from the National Technical Information Service,

U.S. Department of Commerce, 5285 Port Royal Rd., Springfield, VA 22161. 
Pacific Northwest Laboratory

Annual Report for 1990 to the Assistant Secretary for

Environment, Safety, and Health

\section{Part 5: Environment, Safety, Health, and Quality Assurance}

L. G. Faust, R. V. Moraski,

J. M. Selby, and Staff

May 1991

Prepared for

the U.S. Department of Energy

under Contract DE-AC06-76RLO 1830

Pacific Northwest Laboratory

Richland, Washington 99352 



\section{Preface}

This 1990 Annual Report from Pacific Northwest Laboratory (PNL) to the U.S. Department of Energy (DOE) describes research in environment, safety, and health conducted during fiscal year 1990 . The report again consists of five parts, each in a separate volume.

The five parts of the report are oriented to particular segments of the PNL program. Parts 1 to 4 report on research performed for the DOE Office of Health and Environmental Research in the Office of Energy Research. Part 5 reports progress on all research performed for the Assistant Secretary for Environment, Safety, and Health. In some instances, the volumes report on research funded by other DOE components or by other governmental entities under interagency agreements. Each part consists of project reports authored by scientists from several PNL research departments, reflecting the multidisciplinary nature of the research effort.

The parts of the 1990 Annual Report are:

Part 1: Biomedical Sciences
Program Manager:
J. F. Park
J. F. Park, Report Coordinator

S. A. Kreml, Editor

Part 2: Environmental Sciences

Program Manager: R. E. Wildung

M. G. Hefty, Report Coordinator

D. A. Perez, Editor

K. K. Chase, Text Processor

Part 3: Atmospheric Sciences

Program Manager: C. E. Elderkin

C. E. Elderkin, Report Coordinator

E. L. Owczarski, Editor

Part 4: Physical Sciences

Program Manager: L. H. Toburen

L. H. Toburen, Report Coordinator

K. A. Parnell, Editor

Part 5: Environment, Safety, Health, and Quality Assurance Program Managers:
L. G. Faust
R. V. Moraski
J. M. Selby

D. K. Hilliard, Report Coordinator and Editor

Activities of the scientists whose work is described in this annual report are broader in scope than the articles indicate. PNL staff have responded to numerous requests from DOE during the year for planning, for service on various task groups, and for special assistance.

Credit for this annual report goes to the many scientists who performed the research and wrote the individual project reports, to the program managers who directed the research and coordinated the technical progress reports, to the editors who edited the individual project reports and assembled the five parts, and to Ray Baalman, editor in chief, who directed the total effort.

T. S. Tenforde

Health and Environmental

Research Program Office 
Previous reports in this series:

\section{Annual Report for:}

\begin{tabular}{ll}
1951 & HW-25021, HW-25709 \\
1952 & HW-27814, HW-28636 \\
1953 & HW-30437, HW-30464 \\
1954 & HW-30306, HW-33128, HW-35905, HW-35917 \\
1955 & HW-39558, HW-41315, HW-41500 \\
1956 & HW-47500 \\
1957 & HW-53500 \\
1958 & HW-59500 \\
1959 & HW-63824, HW-65500 \\
1960 & HW-69500, HW-70050 \\
1961 & HW-72500, HW-73337 \\
1962 & HW-76000, HW-77609 \\
1963 & HW-80500, HW-81746 \\
1964 & BNWL-122 \\
1965 & BNWL-280, BNWL 235, Vol. 1-4; BNWL-361 \\
1966 & BNWL-480, Vol. 1; BNWL-481, Vol. 2, Pt. 1-4 \\
1967 & BNWL-714, Vol. 1; BNWL-715, Vol. 2, Pt. 1-4 \\
1968 & BNWL-1050, Vol. 1; Pt. 1-2; BNWL-1051, Vol. 2, Pt. 1-3 \\
1969 & BNWL-1306, Vol. 1; Pt. 1-2; BNWL-1307, Vol. 2, Pt. 1-3 \\
1970 & BNWL-1550, Vol, 1;, Pt. 1-2; BNWL-1551, Vol. 2, Pt. 1-2 \\
1971 & BNWL-1650, Vol. 1; Pt. 1-2; BNWL-1651, Vol. 2, Pt. 1-2 \\
1972 & BNWL-1750, Vol. 1;, Pt. 1-2; BNWL-1751, Vol. 2, Pt. 1-2 \\
1973 & BNWL-1850, Pt. 1-4 \\
1974 & BNWL-1950, Pt. 1-4 \\
1975 & BNWL-2000, Pt. 1-4 \\
1976 & BNWL-2100, Pt. 1-5 \\
1977 & PNL-2500, Pt. 1-5 \\
1978 & PNL-2850, Pt. 1-5 \\
1979 & PNL-3300, Pt. 1-5 \\
1980 & PNL-3700, Pt. 1-5 \\
1981 & PNL-4100, Pt. 1-5 \\
1982 & PNL-4600, Pt. 1-5 \\
1983 & PNL-5000, Pt. 1-5 \\
1984 & PNL-5500, Pt. 1-5 \\
1985 & PNL-5750, Pt. 1-5 \\
1986 & PNL-6100, Pt. 1-5 \\
1987 & PNL-6500, Pt. 1-5 \\
1988 & PNL-6800, Pt. 1-5 \\
1989 & PNL-7200, Pt. 1-5 \\
& \\
\hline &
\end{tabular}




\section{Foreword}

Part 5 of the 1990 Annual Report to the U.S. Department of Energy's Assistant Secretary for Environment, Safety, and Health presents Pacific Northwest Laboratory's progress on work performed for the Office of Environmental Guidance, the Office of Environmental Compliance, the Office of Environmental Audit, the Office of National Environmental Policy Act Project Assistance, the Office of Nuclear Safety, the Office of Safety Compliance, and the Office of Policy and Standards. For each project, as identified by the Field Work Proposal, there is an article describing progress made during fiscal year 1990. Authors of these articles represent a broad spectrum of capabilities derived from five of the seven technical centers of the Laboratory, reflecting the interdisciplinary nature of the work. 



\section{Contents}

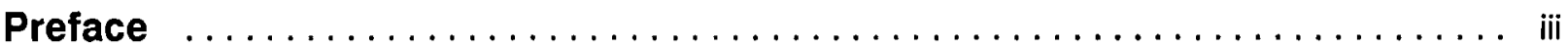

Foreword $\ldots \ldots \ldots \ldots \ldots \ldots \ldots \ldots \ldots \ldots \ldots \ldots \ldots \ldots \ldots \ldots$

Deputy Assistant Secretary for Environment $\ldots \ldots \ldots \ldots \ldots \ldots \ldots \ldots \ldots$

Environmental Protection, Support, and Assistance $\ldots \ldots \ldots \ldots \ldots \ldots \ldots \ldots$

Technical Support During the Review of Proposed EPA Regulations,

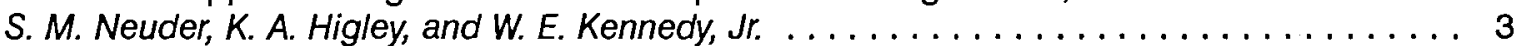

Technical Support to Criteria Development, R. D. Stenner, W. E. Kennedy, Jr.,

W. L. Templeton, T. A. Ikenberry, J. K. Soldat, and L. K. Grove . . . . . . . . . . . . . 3

Development of a DOE Groundwater Protection Strategy, J. A. Joseph,

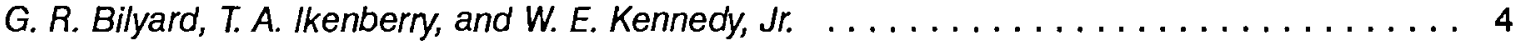

Development of International Exempt Quantities, B. A. Napier,

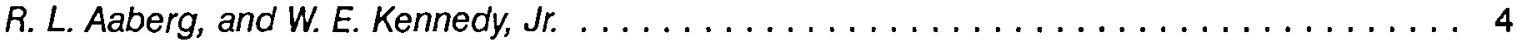

Other Technical Assistance, W. E. Kennedy, Jr., R. D. Stenner,

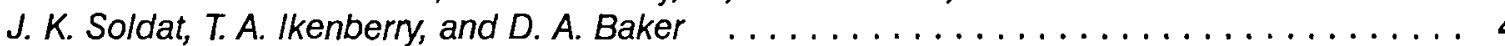

Environmental/Hazardous Waste Risk Assessment $\ldots \ldots \ldots \ldots \ldots \ldots \ldots \ldots \ldots \ldots$

Development of the Multimedia Environmental Pollutant Assessment

System (MEPAS) Methodology, J. G. Droppo, Jr., D. L. Strenge,

J. W. Buck, and B. L. Hoopes ............................ 5

Environmental Guidance Technical Support Project $\ldots \ldots \ldots \ldots \ldots \ldots \ldots \ldots \ldots$

Analysis and Investigation of Environmental Policy and Guidance Issues,

J. F. Keller, D. M. Beck, M. R. Siegel, M. B. Triplett, and J. D. Smith . . . . . . . . . . . 9

Reviewing Key Environmental Regulations and Associated Documents,

C. W. Abrams, B. A. Napier, R. L. Hill, and J. G. Droppo . . . . . . . . . . . . . . . . 10

Risk Assessment, Risk Management, and Risk Communication, J. Longstreth . . . . . . . 10

Risk-Based Standards Project, $G$. R. Bilyard $\ldots \ldots \ldots \ldots \ldots \ldots \ldots \ldots \ldots \ldots \ldots$

Environmental Compliance Technical Support Project . . . . . . . . . . . . . . 13

Development of Compliance Methodologies and Supporting Technical

Analysis, J. F. Keller, C. A. Geffen, K. K. Humphreys, M. R. Siegel, M. G. Woodruff,

A. M. Lesperance, and E. E. Hickey ......................... 13

Reviewing Key DOE Compliance and Policy Documents, J. F. Keller, M. G. Woodruff,

K. K. Humphreys, P. G. Doctor, E. E. Hickey, A. M. Lesperance, J. L. Longstreth,

S. J. Veitenheimer, R. Swahn (ICF, Inc.), K. Medearis (Booz Allen, Hamilton, Inc.),

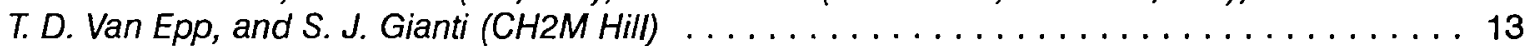

Supporting Day-to-Day Compliance Activities $\ldots \ldots \ldots \ldots \ldots \ldots \ldots \ldots \ldots \ldots \ldots$

National Environmental Policy Act Assistance $\ldots \ldots \ldots \ldots \ldots \ldots \ldots \ldots \ldots \ldots$

Deputy Assistant Secretary for Health $\ldots \ldots \ldots \ldots \ldots \ldots \ldots \ldots \ldots \ldots \ldots$

Beta Measurement Evaluation and Upgrade . . . . . . . . . . . . . . . . . . 19

Beta Dosimeter Development, J. S. Durham, S. E. Merwin, M. H. Smith,

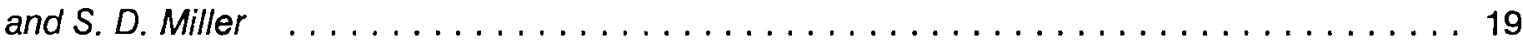

Beta Survey Instrument Development, D. R. Sisk and K. L. Swinth $\ldots \ldots \ldots \ldots \ldots \ldots 20$ 
Beta Spectroscopy Instrument Development, D. R. Sisk and K. L. Swinth $\ldots \ldots \ldots \ldots \ldots 20$

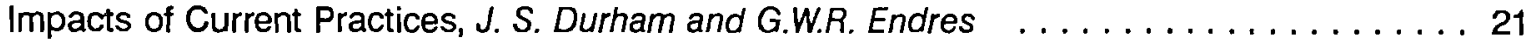

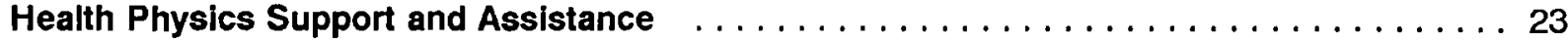

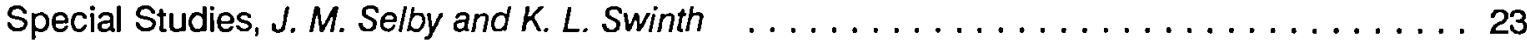

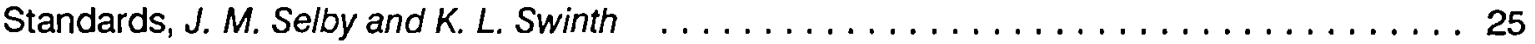

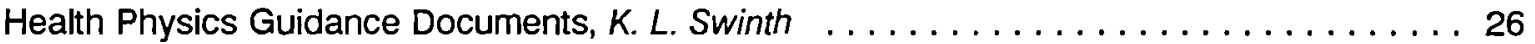

Health Physics Reviews and Technical Assistance to OSPS, K. L. Swinth . . . . . . . 28

Internal DosImetry and Measurement Upgrade $\ldots \ldots \ldots \ldots \ldots \ldots \ldots \ldots \ldots \ldots \ldots$

Software Package for Occupational Internal Dosimetry,

D. L. Strenge, R. A. Peloquin, J. R. Johnson, D. R. Fisher,

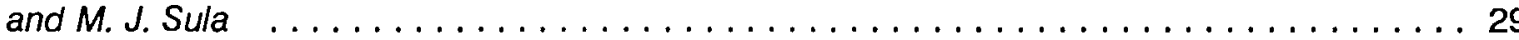

Laboratory Accreditation Support Program $\ldots \ldots \ldots \ldots \ldots \ldots \ldots \ldots \ldots \ldots \ldots \ldots$

External Dosimetry Accreditation Development, J. C. McDonald and R. Harty . . . . . . . . 31

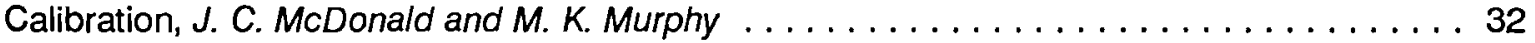

Bioassay Laboratory Accreditation, $P . C$. Olsen $\ldots \ldots \ldots \ldots \ldots \ldots \ldots \ldots \ldots \ldots \ldots$

Instrumentation Testing and Accreditation, K. L. Swinth $\ldots \ldots \ldots \ldots \ldots \ldots \ldots \ldots \ldots$

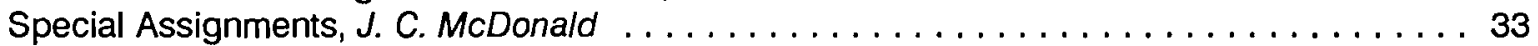

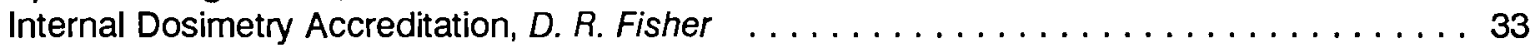

Criteria for Fecal Bioassay, $R$. L. Hill and D. R. Fisher $\ldots \ldots \ldots \ldots \ldots \ldots \ldots \ldots . \ldots . \ldots$

Neutron Dosimetry Evaluation and Upgrade $\ldots \ldots \ldots \ldots \ldots \ldots \ldots \ldots \ldots \ldots$

Field Neutron Spectrometer, L. W. Brackenbush, R. I. Scherpelz, and J. L. Thorngate . . . . 36

Total Dose Meter, L. W. Brackenbush . . . . . . . . . . . . . . . . . . . . . . . . . . . . 36

Combination Thermoluminescence/Track Etch Dosimeter, M. A. Parkhurst,

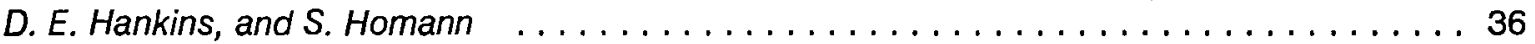

Effective Dose Equivalent (EDE) System, J. E. Tanner, R. J. Traub, and R. D. Stewart . . . . 37

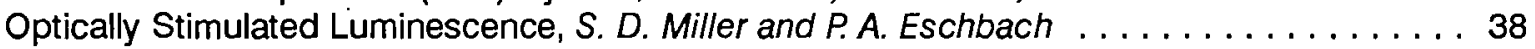

Superheated Drop Detector, D. R. Sisk and R. E. Apfel $\ldots \ldots \ldots \ldots \ldots \ldots \ldots \ldots$

Occupational Protection Program Development and Assessment $\ldots \ldots \ldots \ldots \ldots \ldots$

Environmental Protection Agency (EPA) Protective Action Guide (PAG) Tasks,

L. H. Munson, E. E. Hickey, T. A. Ikenberry, M. A. Kellogg, J. R. Johnson,

G. A. Stoetzel, B. E. Vesper, S. E. Merwin, M. P. Moeller, R. L. Hill, G. F. Martin,

D. W. Blondin, R. W. Schultz, R. F. Darwin, and C. S. Glantz . . . . . . . . . . . . . 39

Workshops on Classification of Events, J. D. Jamison and G. F. Martin . . . . . . . . . 40

Draft of DOE 5500.3A Implementation Guidance, J. D. Jamison and E. E. Hickey . . . . . 40

Assessment Program Development, L. H. Munson, G. R. Cicotte, E. E. Hickey,

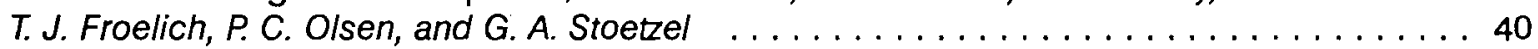

Deputy Assistant Secretary for Safety Appraisals and Quality Assurance . . . . 43

Radiation Protection Support to the Department of Energy

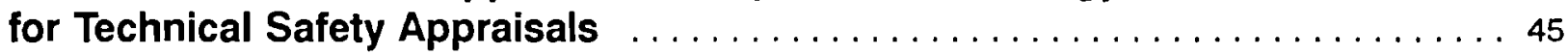

Safety Analysis Report (SAR) Review $\ldots \ldots \ldots \ldots \ldots \ldots \ldots \ldots \ldots \ldots \ldots$ 
Technical Support of Radiation Protection Requirements . . . . . . . . . . . . . . 49

Guidance for Implementation of Revised DOE Orders for Internal Dosimetry,

J. M. Selby and D. R. Fisher

Standard for Implementation of Revised DOE Orders for External Dosimetry,

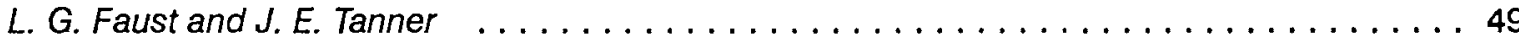

Air Sampling and Monitoring Guidance, B. E. Vesper ................... 49

Guidance for Contamination Control Policy at DOE Sites, L. H. Munson and

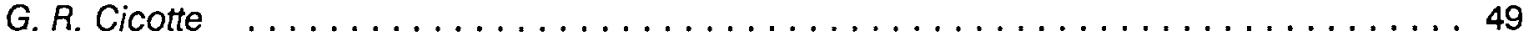

Guidance for Contamination Measurement Levels, $K$. L. Swinth . . . . . . . . . . . . . . 50

5480.11 Upgrades, J. M. Selby and K. L. Swinth . . . . . . . . . . . . . . . . . . . 50

5484.1 Upgrades, J. M. Selby and K. L. Swinth ... . . . . . . . . . . . . . . . . 50

Special Analyses per DOE Request, J. M. Selby and K. L. Swinth ............... 50

\section{Publications and Presentations}

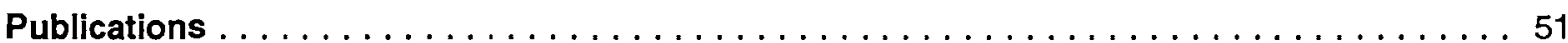

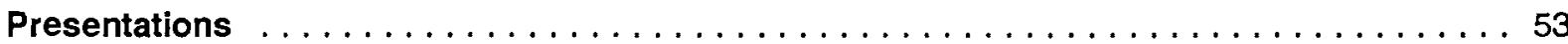

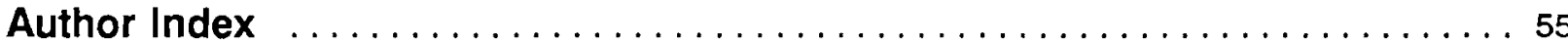

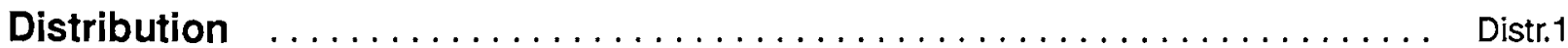


. 
Environment 
. 


\section{Deputy Assistant Secretary for Environment}

The U.S. Department of Energy (DOE) Deputy Assistant Secretary for Environment ensures that activities and installations of the DOE and its contractors are in full compliance with DOE environmental protection policies and applicable federal, state, and local environmental standards and regulations. The Deputy Assistant Secretary for Environment provides technical support and oversight to DOE programs and ensures that all DOE-controlled activities are conducted in an environmentally responsible manner. Pacific Northwest Laboratory (PNL) has established the following four projects in support of the Deputy Assistant Secretary for Environment's mission:

- Environmental Protection, Support, and Assistance

- Environmental/Hazardous Waste Risk Assessment

- Environmental Guidance Technical Support Project

- Environmental Compliance Technical Support Project

- National Environmental Policy Act Assistance 
. 


\title{
Environmental Protection, Support, and Assistance
}

\author{
Project Manager: W. E. Kennedy, Jr.
}

Pacific Northwest Laboratory (PNL) continued to provide technical assistance to the U.S. Department of Energy (DOE) Deputy Assistant Secretary for Environment through a project with the Office of Environmental Guidance (OEG). Assistance from PNL included 1) technical support during the development of comments on proposed draft Environmental Protection Agency (EPA) regulations on the treatment, storage, and disposal of high-level and low-level radioactive waste, 2 ) the development and revision of draft technical requirements to support the revised DOE Order concerning environmental radiation protection, 3) technical support during the development of a DOE groundwater protection strategy, 4) support to the development of international exempt quantities, and 5) additional support efforts concerning technical reviews and comments on draft public radiation exposure standards and regulations.

\section{Technical Support During the Review of Proposed EPA Regulations}

\section{S. M. Neuder, K. A. Higley, and W. E. Kennedy, Jr.}

Proposed changes to environmental regulations for high-level and low-level radioactive waste disposal are being developed by the EPA. These regulations could have a major impact on the operation of DOE nuclear facilities. In response to EPA requests for comments, DOE OEG coordinated the development of comments on these draft regulations by establishing DOE Headquarters Steering Groups and Technical Resource Groups consisting of contractor technical representatives. To further support DOE in this effort, PNL assigned Stan M. Neuder through the PNL Washington, D.C. Office as part of this project. Stan Neuder was able to provide daily support during the development and review of the comments from the DOE Operations and Programs Office representatives. The technical comments included information on the potential economic costs of alternative radiation protection standards and estimates of the potential health impacts of the proposed regulations. The interaction of the DOE Steering Groups with the Technical Resource Groups provided technically credible and detailed comments consistent with DOE policy. The resulting comments have been provided to EPA and are currently being considered through an open dialogue process.

\section{Technical Support to Criteria Development}

R. D. Stenner, W. E. Kennedy, Jr., W. L. Templeton, T. A. Ikenberry, J. K. Soldat, and L. K. Grove

In support of DOE's development of the revised environmental radiological protection Order (DOE 5400.5, "Radiation Protection of the Public and the Environment"), PNL staff contributed by developing technical criteria in a number of areas. Some of these criteria are included as draft requirements or guidance for effluent monitoring and environmental surveillance in documentation supporting the revised DOE environmental Orders. The technical criteria are those identified in other DOE Orders (for consistency within the DOE system), those identified in other established or pending federal regulations, or those from other sources that represent sound technical practice. PNL technical experts also produced draft technical documents providing guidance on 1) establishing environmental programs to maintain public radiation doses "As Low As Reasonably Achievable" (ALARA) and 2) determining the "Best Available Technology" (BAT) for treating liquid radioactive effluents. In addition, PNL technical experts participated in criteria development efforts with the International Atomic Energy Agency (IAEA) concerning model validation studies using the Chernobyl data and the estimation of radiation doses to biota from radioactive effluents from operating nuclear facilities. 


\section{Development of a DOE Groundwater Protection Strategy}

\author{
J. A. Joseph, G. R. Bilyard, T. A. Ikenberry, and \\ W. E. Kennedy, Jr.
}

During January 1990, the EPA issued a draft document concerning groundwater principles and an options paper on the state/federal relationship for groundwater protection. In an effort to provide the DOE Operations Office with a strategic framework for groundwater protection, and to ensure that the DOE strategic framework is used constructively, DOE OEG convened a Technical Work Group. The objectives of the Work Group are to finish the draft DOE groundwater protection strategy and to assist in developing a consistent DOE position on groundwater issues and requirements. PNL technical support to this Work Group included providing briefing materials on DOE and EPA efforts to develop groundwater protection strategies, documenting the need for a DOE groundwater protection strategy, and defining the purposes of this strategy. Other technical support included developing background papers on groundwater classification, determining a point of compliance, and determining a process for establishing alternative concentration levels for compliance.

\section{Development of International Exempt Quantities}

\section{B. A. Napier, R. L. Aaberg, and W. E. Kennedy, Jr.}

The International Atomic Energy Agency (IAEA) is conducting a program to establish internationally agreed principles for the exemption of radiation sources and practices from regulatory control. Example exemption levels for material to be sent for incineration and/or disposal at municipal landfill sites were previously derived based on a preliminary set of exemption principles. During 1990, the
IAEA continued their program by holding technical committee meetings on the application of exemption principles to 1) disposal of radioactive wastes arising from hospitals and research establishments and 2) the recycle or reuse of materials from nuclear facilities. Two PNL staff members served as consultants to these IAEA technical committees and attended their meetings held in Vienna, Austria. They helped draft the consultants' report concerning hospital and research facility wastes, and drafted the consultants' report on recycle and reuse. PNL also provided computer support for the radiation exposure pathway and scenario analysis. This effort is of technical interest to DOE $O E G$ as part of the development of risk-based standards for DOE operations.

\section{Other Technical Assistance}

\section{W. E. Kennedy, Jr., R. D. Stenner, J. K. Soldat, T. A. Ikenberry, and D. A. Baker}

Through a technical assistance task, PNL further supports OEG by providing rapid-turnaround technical responses or reviews to priority requests. These requests typically are in areas that fall outside the scope of the identified tasks but have an urgency to DOE and its operations. During 1990 these special assistance tasks included: 1) participation in an internal DOE low-level radioactive waste Performance Assessment peer review panel, 2) support to individuals developing screening models for the National Council on Radiological Protection and Measurements (NCRP), 3) participation in American National Standards Institute, Inc. (ANSI) standards committee efforts, 4) support to individuals contributing to the development of a new lung model for the International Commission on Radiological Protection, and 5) preparation of review comments on various draft or final technical reports and standards from national and international authorities. 


\title{
Environmental/Hazardous Waste Risk Assessment
}

\author{
Project Manager: J. G. Droppo, Jr.
}

Pacific Northwest Laboratory (PNL) continues to provide technical guidance and support to the U.S. Department of Energy (DOE) in the environmental/hazardous waste risk assessment area. The overall objective of PNL's efforts was to assist DOE in developing technical methods in support of guidance for its operations and to ensure compliance of these operations with applicable environmental regulations and standards. The major effort during FY 1990 was the completion of the documentation of the Multimedia Environmental Survey.

\section{Development of the Multimedia Environmental Pollutant Assessment System (MEPAS) Methodology}

\author{
J. G. Droppo, Jr., D. L. Strenge, J. W. Buck, and \\ B. L. Hoopes
}

The Multimedia Environmental Pollutant Assessment System (MEPAS) is a methodology for assessing health impacts from the release of hazardous chemical and radioactive materials. It was developed by the Pacific Northwest Laboratory (PNL) for the U.S. Department of Energy (DOE) Environmental Survey (Survey) and is a component of DOE's Risk Information System (RIS).

MEPAS uses environmental contaminant concentrations to estimate potential health impacts based on an assessment of major pathways. These impact estimates are a major source of risk information for prioritizing potential environmental problems. They provide a metric for ranking, screening, and other risk evaluation applications.

The MEPAS mathematical pathway algorithms are based on standard modeling approaches such as those recommended by the Environmental Protection Agency (EPA 1988). These algorithms use site-specific characteristics to estimate both emission and contaminant migration from a site to receptors. Groundwater, overland, surface water, and atmospheric pathway components are used to simulate multimedia contaminant migration.

The MEPAS methodology represents an expanded version of the Remedial Action Priority System (RAPS) methodology. To meet the Survey's need for a ranking tool that could evaluate active as well as inactive sites, the RAPS code was expanded in FY 1987 to allow consideration of active sites. The first operational integrated MEPAS code was delivered to DOE in September 1987. The results of a preliminary prioritization effort for $16 \mathrm{DOE}$ defense program (DP) sites using this first version was released in 1988 (DOE 1988). The second version of the MEPAS code with a user friendly interface (MEPAS shell) was delivered in September 1988. All versions of MEPAS are implemented for operation on a personal computer. The MEPAS shell guides the user in problem definition, data collection and entry, data review and documentation, and running applications.

Technical support was provided in FY 1990 to complete application of MEPAS to the 26 DOE facilities being considered by the Survey. During the year, PNL provided updates to the MEPAS code and databases on an as-needed basis and helped in an audit of the records of assumptions for Survey applications.

In FY 1990 the final MEPAS documents were completed. The MEPAS documentation consists of the following reports: supplemental formulation (Droppo et al. 1989a), constituent database (Strenge and Petersen 1989), testing results (Whelan et al. 1989), short users guide (Buck et al. 1989), guidelines for MEPAS applications (Droppo et al. 1989b), input parameter guidance (Droppo et al. 1989c), sensitivity study results (Doctor et al. 1990), and an ranking parameter analysis (Droppo et al. 1990a). In addition, an expert systems book includes a chapter on the MEPAS software (Droppo and Hoopes 1990). 
The supplemental formulation report documents the MEPAS updates to the original RAPS formulation report (Whelan et al. 1987). Enhancements to the groundwater, surface water, overland, atmospheric, and exposure components are documented. These enhancements include a revision in the integration method for the waterborne pathway and new components for wetlands, gaseous emissions (volatilization), atmospheric complex terrains, mass budget formulations, and environmental decay. Several new exposure components are also described along with enhancements to the exposure pathways computations.

To ensure consistent Survey application to DOE sites, a MEPAS constituent database was used to define values of physical, chemical, and toxicological parameters at all sites (Strenge and Petersen 1989). The constituent database report was written to document magnitudes and sources of these data. Currently, 394 chemicals are contained in this database.

During FY 1990 a formal parametric sensitivity analysis of the MEPAS was completed. This effort was performed to evaluate the level of uncertainty associated with the use of the model. This analysis determined the sensitivity of the Hazard Potential Index (HPI) to uncertainty in user-definable model inputs for combinations of transport pathway and exposure routes anticipated for environmental problems at DOE sites. Representative scenarios were selected from the preliminary Survey effort at 16 DOE DP sites. The results of the sensitivity analysis define the variability in $\mathrm{HPI}$ expected for a well-characterized site and combinations of conditions and exposures represented in the test scenarios.

An analysis of the preliminary rankings at the 16 DOE DP sites was also completed in FY 1990. Comparisons were made of the rankings of environmental problems using the HPI and additional public health parameters. The results show that important information regarding impacts may be lost if a single parameter is used to rank the impacts of environmental problems. Instead, a series of parameters are required to characterize each environmental problem.

Because it is applicable to a wide range of potential environmental problems, the MEPAS is expected to be used in DOE applications beyond the Survey. A number of these efforts are currently under way. Droppo et al. (1990b) used MEPAS to incorporate risk considerations in the design of the waste characterization program for single-shell tanks at Hanford. MEPAS is also under consideration as a starting point for the Office of Environmental Restoration development of a risk computation module for the DOE Prioritization System.

During FY 1991, PNL is to provide technical assistance in external reviews of the MEPAS portion of the RIS. Reviews are to be undertaken by the National Academy of Sciences and other DOE laboratories. The DOE also plans to have a formal public review of these methodologies. PNL will also provide assistance to DOE in the completion of the Final Summary Report for the Survey.

\section{References}

Buck, J. W., B. L. Hoopes, and D. R. Friedrichs. 1989. Multimedia Environmental Pollutant Assessment System (MEPAS): Getting Started with MEPAS. PNL-7126, Pacific Northwest Laboratory, Richland, Washington.

Doctor, P. G., T. B. Miley, and C. E. Cowan. 1990. Multimedia Environmental Pollutant Assessment System (MEPAS) Sensitivity Analysis of Computer Codes. PNL-7296, Pacific Northwest Laboratory, Richland, Washington.

DOE. 1988. Environmental Survey Preliminary Summary Report of the Defense Production Facilities. DOE/EH-0072, U.S. Department of Energy; Environment, Safety, and Health; Office of Environmental Audit; Washington, D.C.

Droppo, J. G., Jr., J. W. Buck, D. L. Strenge, and M. R. Siegel. 1990a. Analysis of Health Impact Inputs to the U.S. Department of Energy's Risk Information System. PNL-7432, Pacific Northwest Laboratory, Richland, Washington.

Droppo, J. G., Jr., J. W. Buck, S. Wilbur, D. L. Strenge, and M. D. Freshley 1990b. SingleShell Tank Constituent Rankings for Use in Preparing Waste Characterization Plans. PNL-7572, Pacific Northwest Laboratory, Richland, Washington. 
Droppo, J. G., Jr., G. Whelan, J. W. Buck, D. L. Strenge, B. L. Hoopes, and M. B. Walter. 1989a. Supplemental Mathematical Formulations: The Multimedia Environmental Pollutant Assessment System (MEPAS). PNL-7201, Pacific Northwest Laboratory, Richland, Washington.

Droppo, J. G., Jr., and B. L. Hoopes. 1990. "Remedial Action Priority and Multimedia Environmental Pollutant Assessment Systems." In Expert Systems for Environmental Applications, J. M. Hushon, Editor, American Chemical Society.

Droppo, J. G., Jr., D. L. Strenge, J. W. Buck, B. L. Hoopes, and G. Whelan. 1989b. Multimedia Environmental Pollutant Assessment System (MEPAS) Application Guidance Volume 1 - User's Guide. PNL-7216, Pacific Northwest Laboratory, Richland, Washington.

Droppo, J. G., Jr., D. L. Strenge, J. W. Buck, B. L. Hoopes, and G. Whelan. 1989c. Multimedia Environmental Pollutant Assessment System (MEPAS) Application Guidance Volume 2 Guidelines for Evaluating MEPAS Input Parameters. PNL-7216, Pacific Northwest Laboratory, Richland, Washington.
EPA. 1988. Superfund Exposure Assessment Manual. OSWER Directive 9285.5-1, Office of Remedial Response, Office of Solid Waste and Emergency Response, U. S. Environmental Protection Agency, Washington, D.C.

Strenge, D. L., and S. R. Peterson. 1989. Chemical Data Bases for the Multimedia Environmental Pollutant Assessment System (MEPAS): Version 1. PNL-7145, Pacific Northwest Laboratory, Richland, Washington.

Whelan, G., D. L. Strenge, J. G. Droppo, Jr., and B. L. Steelman. 1987. The Remedial Action Priority System (RAPS): Mathematical Formulations. PNL-6200, Pacific Northwest Laboratory, Richland, Washington.

Whelan, G., J. G. Droppo, Jr., D. L. Strenge, M. B. Walter, and J. W. Buck. 1989. A Demonstration of the Applicability of Implementing the Enhanced Remedial Action Priority System (RAPS) for Environmental Releases. PNL-7102, Pacific Northwest Laboratory, Richland, Washington. 



\section{Environmental Guidance Technical Support Project}

\section{Project Manager: T. L. Kuusinen}

The Environmental Guidance Technical Support Project provides assistance to the U.S. Department of Energy (DOE) in assessing the needs and developing the necessary guidance and policies to ensure that DOE's facilities are operated in a manner that protects human health and the environment. This support is provided to the Resource Conservation and Recovery Act (RCRA)/ Comprehensive Environmental Response, Compensation, and Liability Act (CERCLA) Division within the Office of Environmental Guidance (OEG).

Under this project, Pacific Northwest Laboratory (PNL) 1) assesses policy needs; 2) develops guidance manuals, workshops, and reports in support of DOE policies, and 3) investigates environmental policy and guidance issues. PNL also reviews and comments on guidance and policy documents important to the DOE's environmental guidance activities.

\section{Analysis and Investigation of Environmental Policy and Guidance Issues}

\section{J. F. Keller, D. M. Beck, M. R. Siegel, M. B. Triplett, and J. D. Smith}

Technical highlights during FY 1990 included a variety of analysis and investigation activities that have increased the visibility and credibility of the OEG. For example, PNL and its subcontractor developed a manual for guidance on land disposal restrictions treatability variance. PNL also supported the development of the DOE Mixed Waste Strategy Report, which resulted in the Environmental Protection Agency granting a twoyear national capacity for some radioactive mixed waste.

A continuing effort is the investigation of the potential risks and benefits of applying the "observational approach" to DOE remediation efforts. The observational approach is a method for achieving site remediation that will favor action over study and will recognize the uncertainties associated with site characterization and the implementation of a remedial alternative. The results of this investigation, which concluded that the observational approach would be beneficial, were summarized in a joint PNL/OEG presentation. As a result, PNL is now providing technical assistance to the Office of Environmental Restoration and Waste Management to incorporate the observational approach in environmental restoration efforts at a DOE site.
Building upon earlier activities, PNL developed a comprehensive guidance manual on RCRA closure. The manual, which was tailored to the DOE's activities and needs, will guide field offices in their closure activities. This work was integrated with the radioactive mixed-wastes and land disposal restriction activities mentioned above.

Project staff also supported the OEG in its development of a public participation guidance manual on implementing a DOE community relations program under the Superfund Amendments and Reauthorization Act (SARA). As part of this effort, PNL conducted two workshops on community relations/public involvement. The workshops provided participants with an understanding of DOE philosophies and policies related to community relations/public involvement; an overview of the community relations/public involvement requirements; identification of successful strategies and "lessons learned" for implementing community relations/public involvement programs and development of information networks for individuals responsible for implementing DOE community relations/public involvement programs.

In FY 1990 staff began to help personnel at DOE Headquarters develop a graphic approach to environmental guidance (GAeG) for CERCLA/ RCRA activities at DOE sites. The primary focus of the work is to prepare graphical road maps, stepby-step instructions, graphical summaries, and self-audit checklists that provide framework guidance for different aspects of the CERCLA and 
RCRA regulations that are difficult for site managers, or that are commonly encountered and often misinterpreted. As part of this effort, PNL is developing a GAeG package for CERCLA removal actions for DOE's review.

The development of an overall environmental protection policy and strategy for the DOE is being investigated. The overall strategy would coordinate individual strategies for the protection of groundwater, soil, air, and surface water within the framework of a set of guiding principles. It would provide a unified approach to environmental protection for the DOE complex that would guide environmental restoration, waste management, siting, and decontamination and decommissioning activities at sites and facilities across the DOE complex.

\section{Reviewing Key Environmental Regula- tions and Associated Documents}

\section{W. Abrams, B. A. Napier, R. L. Hill, and J. G. Droppo}

Another activity conducted in FY 1990 is the review of the draft Final Rule on revisions to the Hazard Ranking System (HRS). PNL also developed a statement of work for the comparative review of the proposed HRS and the revised HRS. In addition, PNL provided an analysis of environmental reports, with biweekly listings of the reports and supporting fact sheets as requested by the Office of Environment, Safety, and Health.

PNL also provided assistance to the OEG in reviewing the DOE Proposed Emergency Preparedness Rule and Revised 5500 Series Orders for their inclusion and emergency response and preparedness responsibilities under CERCLA, SARA, and National Contingency Plan authorities.

\section{Risk Assessment, Risk Management, and Risk Communication}

\section{J. Longstreth}

The U.S. Department of Energy's (DOE) Office of Environmental Guidance (OEG) has the responsibility for providing guidance and policy information to the DOE regarding how to develop, use, and communicate risk-related information and practices. The OEG ensures that the field offices receive information on DOE's policies and provides guidance to ensure that DOE-controlled activities are conducted in a manner that protects human health and the environment. As part of this responsibility, OEG is often asked to supply information on potential risks at various DOE sites from specific contaminants or operations and put those risks into the proper perspective. To support these activities, the OEG needs to have information and methods available for effectively communicating this information to the field, to Congress, and to the general public.

In FY 1990, the Pacific Northwest Laboratory began to develop a project that will provide technical support to the OEG in the development of an integrated program in risk assessment, risk management, and risk communication. PNL attended a risk assessment and risk communication course and presented the OEG with information covered by the course. In addition, PNL provided the OEG support with regard to risk information requests. PNL also initiated work on assembling pertinent information with regard to background levels of radionuclides. Finally, in order to keep the OEG abreast of risk assessment, risk management, and risk communication developments, PNL began gathering background data from various sites for input into a DOE RiskRelated Activities Director (DOE-RAD).

\section{Risk-Based Standards Project}

\section{G. R. Bilyard}

The Pacific Northwest Laboratory (PNL) assists the U.S. Department of Energy (DOE) Office of Environmental Guidance in conducting baseline activities that will provide input to decisions regarding the development and application of standards for environmental restoration, waste management, and decontamination and decommissioning activities. These baseline activities will include identifying outstanding issues that are related to the development of standards, and recommending actions that will lead to the development of needed standards. These baseline activities are a necessary prerequisite to developing standards and associated guidance because they will identify: 1) contaminants for which standards are needed, 2) existing relevant federal risk-based standards and guidance, and 3) gaps and inconsistencies among the existing standards that are potentially applicable to DOE. Technical accomplishments for this project during FY 1990 are summarized below. 
PNL inventoried the hazardous and radioactive constituents that have been used historically, that are presently being used, and that have been detected in environmental media on DOE sites. Information was collected from the Hanford, Savannah River, and Oak Ridge sites to identify chemicals and radionuclides that may be important to DOE activities. This information was compiled into a draft report for review by DOE Headquarters.

PNL also compiled a second draft report that identifies federal standards and criteria (e.g., DOE, Environmental Protection Agency, and Nuclear Regulatory Agency) that are available in existing regulations, guidance, and DOE Orders, and that are applicable to the constituents of concern to DOE. This report identified the sources of the applicable standards and included references to the appropriate statutes, regulations, and DOE Orders.

PNL will complete the baseline activities during the first quarter of FY 1991 by cross-matching constituents of concern to DOE (identified in the first draft report) with the existing federal riskbased standards (identified in the second draft report). This cross-match will identify gaps and inconsistencies among the existing set of federal risk-based standards, thereby identifying the scope and magnitude of the proposed standards development activities. 


\section{Environmental Compliance Technical Support Project}

\section{Project Manager: C. A. Geffen}

The Environmental Compliance Technical Support Project provides assistance to the U.S. Department of Energy (DOE) Office of Environmental Compliance (OEC) in fulfilling its oversight and technical assistance responsibilities to ensure that DOE facilities and operations comply with DOE environmental Orders and other federal, state, and local environmental requirements. The technical support provided under this project by Pacific Northwest Laboratory (PNL) assists DOE by: 1) developing compliance methodologies and supporting technical analysis to be used by DOE to ensure compliance and consistency across the DOE complex, 2) reviewing and commenting on compliance and policy documents important to DOE's environmental activities, and 3) supporting day-to-day compliance activities. Progress made on this project during FY 1990 is highlighted in the following subsections.

\section{Development of Compliance Methodologies and Supporting Technical Analyses}

\author{
J. F. Keller, C. A. Geffen, K. K. Humphreys, \\ M. R. Siegel, M. G. Woodruff A. M. Lesperance, \\ and E. E. Hickey
}

Technical highlights during FY 1990 included the continued development of a manual for reviewing all Resource Conservation and Recovery Act (RCRA) and Comprehensive Environmental Response, Compensation, and Liability Act (CERCLA) documentation. This manual is intended to help ensure that environmental documents receive consistent reviews from OEC's policy perspective. Toward that end, the manual identifies critical elements within each regulatory document that must be addressed before submission to regulatory agencies, and highlights important policy issues for consideration in the preparation of documents for DOE.

PNL is also identifying ways to devise a program that will enable the OEC to track key CERCLA and RCRA corrective action decision points and monitor activities in this area. These activities will help ensure a consistent approach in the DOE's efforts to satisfy CERCLA/RCRA requirements and respond to inquiries by outside groups reviewing the DOE's CERCLA and RCRA corrective action implementation and documentation of its sitespecific activities.

In addition, $\mathrm{PNL}$ is summarizing health assessment activities from the Agency for Toxic Substance and
Disease Registry. The DOE can use this information in reviewing its environmental-related health assessment activities.

PNL provided support to OEC in developing a standard framework for reporting information to comply with the requirements of SEN-7 (Policy on Line Management's Responsibility to Achieve Environmental Compliance). In addition, PNL also reviewed complex-wide practices for the disposal of solvent laden wipes.

According to the Rocky Flats Plant FFCA, within 330 days of the effective date of the Federal Facility Compliance Agreement (FFCA), DOE was required to prepare a report describing the methods by which DOE would achieve compliance with Land Disposal Restrictions. PNL provided assistance to DOE in preparing this one-year report.

\section{Reviewing Key DOE Compliance and Policy Documents}
J. F. Keller, M. G. Woodruff, K. K. Humphreys,
P. G. Doctor, E. E. Hickey, A. M. Lesperance, J. L. Longstreth, S. J. Veitenheimer, R. Swahn (ICF, Inc.), K. Medearis (Booz Allen, Hamilton, Inc.), T. D. Van Epp, and S. J. Gianti (CH2M Hill)
PNL has reviewed and commented on over 40 site-specific environmental -reports and approxi- mately 40 Environmental Implementation Plans. Examples of the site-specific reports included: Remedial Investigation/Remedial Feasibility Investigation (RI/RFI) Work Plans, Field Sampling 
Plans, Quality Assurance Plans, Oil Spill Prevention Plans, Feasibility Study Screenings, Risk Assessments, Engineering Design Criteria, and Engineering Evaluation Cost Analysis (EECA).

As required under DOE Order 5400.1, each DOE site submits an environmental report each year. While the reports focus on environmental monitoring, other environmental program information is also included. Each year, DOE combines the data from the individual site reports to provide a summary of total pollutant levels from DOE facilities. Having assisted DOE in preparing previous summary reports, PNL recommended changes to the format and content of the site and summary reports. Specifically, PNL 1) reviewed the 1988 site environmental reports and other data that were provided, 2) prepared a summary of the environmental reports, 3) prepared a summary of the compliance memoranda submitted by the sites, 4) prepared a report recommending modifications to the radiological and nonradiological reporting in the 1988 site environmental reports, and 5) prepared various option papers regarding the purpose and content of the site and summary reports. PNL is continuing its support to the OEC in finalizing the Draft 1988 Summary Report, preparing the Draft 1989 Summary Report, and providing guidance to sites on preparing their Annual Site Environmental Reports.

\section{Supporting Day-to-Day Compliance Activities}

PNL has provided direct, on-site support in the technical editing of various Tiger Team reports, Congressional reports, and transcripts of Congressional hearings. PNL has also provided direct, on-site support in preparing graphics and presentation materials for the OEC. 


\section{National Environmental Policy Act Assistance}

\section{Project Manager: J. Longstreth}

Pacific Northwest Laboratory continues to provide technical assistance to the U.S. Department of Energy Office of National Environmental Policy Act (NEPA) Oversight as well as to field office personnel in efforts to better implement the requirements of NEPA for DOE projects. The issuance of Secretary of Energy Notice 15 (SEN 15) has reinforced the importance of NEPA compliance across the DOE complex and the need for early involvement of the NEPA Office in the development of complete and comprehensive NEPA documentation. 


$$
8^{\text {thath }}
$$


. 


\section{Deputy Assistant Secretary for Health}

To establish and maintain an effective radiation protection program, the U.S. Department of Energy (DOE) Assistant Secretary for Safety, Health, and Environment has assigned to the Office of Health (OH) the responsibility for developing an effective applied research and development program. This office is also responsible for the conduct of DOE-wide independent overview, support, and counsel in all health disciplines. The objectives of these programs are to aid DOE in ensuring that the activities of DOE and its contractors are in full compliance with applicable health standards and regulations, and to provide technical support to the DOE Assistant Secretary for Environment, Safety, and Health. To accomplish this, Pacific Northwest Laboratory (PNL) was established as a lead laboratory in health physics to conduct projects that assist DOE in achieving its mission. Some of the projects are:

- Beta Measurement Evaluation and Upgrade

- Health Physics Support and Assistance to the Department of Energy

- Internal Dosimetry and Measurement Upgrade

- Laboratory Accreditation Support Program

- Neutron Dosimetry Evaluation and Upgrade

- Occupational Protection Program Development and Assessment 
列 


\title{
Beta Measurement Evaluation and Upgrade
}

\author{
Project Managers: L. G. Faust, G.W.R. Endres, and J. S. Durham
}

The Beta Measurement Evaluation and Upgrade Project is designed to provide continuing identification and resolution of significant problems that affect field measurement of beta dose and to ensure that U.S. Department of Energy (DOE) facilities can comply with applicable standards. The objective of this project is to investigate and upgrade beta radiation measurements by developing improved personnel beta dosimeters and instruments used in DOE facilities and to provide direction to DOE.

The work performed during fiscal year (FY) 1990 can be classified into four major areas: 1) dosimeter development, 2) survey instrument development, 3) spectrometer development, and 4) theoretical considerations. Progress made in these four areas during FY 1990 is discussed in the following subsections.

\section{Beta Dosimeter Development}

\section{J. S. Durham, S. E. Merwin, M. H. Smith, and} S. D. Miller

The objectives of this task are to identify and develop new and innovative beta dosimeters for assessing beta dose and for estimating beta spectra. Three types of dosimetry being further developed, tested, and evaluated are discussed in the following subsections.

\section{Laser-Heated Thermoluminescent Dosimetry (TLD)}

The concept of using an infrared (IR) laser to provide the necessary heating for readout of TLDs was evaluated previously. It is apparent the TLD reader concept is fast, accurate, reproducible, and highly sensitive when used with a thin TLD design. The results obtained by using IR laser heating of thin TLDs can be expected to be superior to the results obtained by conventional readout methods. Laser heating of thin TLDs can provide the ability to measure very low doses, even in a highbackground environment. Of the three thin TLD designs evaluated previously, $\mathrm{CaSO}_{4}$ :Dy appears to be the best, followed closely by $\mathrm{MgB}_{4} \mathrm{O}_{7}$ :Dy. Both of these thin TLDs have a very flat energy response and both have the potential to measure doses on the order of $1 \mathrm{mrad}$.

The laser-TLD reader was sent to International Sensor Technology (IST) for a complete renovation and upgrade. Delays in funding, procurement, and hardware combined to delay delivery of the upgraded reader for the entire fiscal year. Although no progress toward evaluation of the reader was attained, considerable progress was made in identifying candidate TLD designs for testing. One of these designs included very thin $\left(10 \mathrm{mg} / \mathrm{cm}^{2}\right)$, small grain size $(<20 \mu \mathrm{m})$ TLD powder bound to a Kapton substrate with silicon. This design was manufactured in both an oxygen and a nitrogen atmosphere for sensitivity comparison. A second TLD design incorporates a $7.5 \mathrm{mg} / \mathrm{cm}^{2}$ sintered powder, i.e., a thin version of the standard $\mathrm{CaF}_{2}: \mathrm{Mn}$ TLD manufactured by Harshaw.

\section{Exoelectron Dosimetry}

The evaluation of exoelectron dosimetry was completed during FY 1990. A new, automated reader with a multianode counter was tested and evaluated, new dosimeters were characterized, and field tests of the exoelectron dosimeters (EEDs) were performed. A final report was provided to the sponsor.

The new automated reader provided a fast and reliable method of obtaining dose information from EEDs. The dose upper limit that could be measured was determined to be 10 rad using the automatic heating cycle and 25 rad using a slower heating cycle. The technical specifications indicated that the upper limit was $25 \mathrm{rad}$ with the automatic cycle. However, the slower heating rate did not seriously increase the readout time. 
Overall, the drawbacks to using EEDs for routine personnel dosimetry were found to outweigh the benefits. The dosimeters are very delicate; any contact with the sensitive layer will greatly affect the dose response characteristics of the EED. This problem precludes the use of EEDs for routine personnel dosimetry applications.

The sensitivity of beryllium oxide to beta and gamma radiation is unsurpassed. The EEDs were found to meet DOELAP criteria with a maximum bias of $19 \%$. The standard deviation of readings were typically between $6 \%$ and $10 \%$ for all photon, beta, and mixtures of radiation tested. Results of the evaluation were published in Radiation Protection Dosimetry (Merwin 1989). The dosimetric value of EEDs was demonstrated during a field test performed during September 1990. Measurements were performed on pure ${ }^{90} Y$ sources in various geometries to determine correction factors for TLD-based extremity dosimeters. The measurements, which were performed with a paste-filled surgeon's glove as a hand phantom, simulated several exposure scenarios routinely encountered during handling of the source. The EED measurements were invaluable in providing accurate dosimetry required for evaluating the maximum dose to $1 \mathrm{~cm}^{2}$ and determining the correction factor to be applied to TLD-based extremity dosimeters. Thus it was shown that EEDs, when used by trained dosimetry professionals, are a valuable and reliable resource for special dosimetry applications.

The conclusions from the EED study indicate that EEDs are not suited for routine personnel dosimetry applications. However, their unsurpassed sensitivity to beta, gamma, and mixed radiation fields makes them an ideal dosimeter when used by trained dosimetry professionals. The ability to perform EED measurements should be maintained for special dosimetry applications.

\section{COSL Readout of Thin Dosimeters}

With the delays in the upgrade of the laser-TLD reader, attention was focused on a new technique to read out the same thin dosimeters used with TLD readout. The new method, cooled optically stimulated luminescence (COSL), uses optical stimulation by blue light to transfer a small percentage of high-temperature traps created by interactions of radiation with the material to low-temperature traps. By cooling the dosimeters to liquid nitrogen temperatures during stimulation, the low temperature traps remain stable until the dosimeter is allowed to warm to room temperature. Light that is proportional to that received by the dosimeter is emitted from the traps and counted.

The COSL process is expected to be more sensitive than TLD readout since there is no background incandescence emitted during COSL and the light collection efficiency can be improved by placing the photomultiplier tube almost in contact with the dosimeter. The work performed during FY 1990 determined that COSL readout is feasible, but great improvements must be made in the sensitivity.

The minimum level of detection was found to be around $1 \mathrm{rad}$. Improvements in the dosimeter design were identified and are expected to decrease this level by a factor of 100 or more. A report on the feasibility of COSL in beta dosimetry was provided to the sponsor.

\section{Beta Survey Instrument Development}

\section{R. Sisk and K. L. Swinth}

This task is dedicated to the development of instrumentation to enable the accurate measurement of both penetrating and nonpenetrating radiations.

Evaluation of the prototype instrument was completed, including serviceability, construction, and field acceptance. The calibration software that is used for laboratory calibration of the instrument was completed and the development of the correction factor software was initiated. Calibrations of the instrument using a ${ }^{137} \mathrm{Cs}$ source were completed.

\section{Beta Spectroscopy Instrument Development}

\section{R. Sisk and K. L. Swinth}

This task is dedicated to the development of spectrometers for the characterization of beta fields in the workplace. Optimization, fine-tuning, and field testing of the beta-gamma field spectrometer continued during FY 1990. 
The evaluation of the dose calculation software was completed and sub-miniature preamplifiers were evaluated for use with the system. Improvements were made to the design of the proportional counter to increase the signal-to-noise ratio by utilizing an improved preamplifier design. The serviceability of the spectrometer was improved by redesigning the windows to facilitate their removal and replacement.

A field spectrometer was designed and implemented into a "suitcase spectrometer" concept for the PANTEX site. The suitcase spectrometer was developed under the Neutron Measurement and Evaluation Program for DOE. A trip to PANTEX for training and field testing of the spectrometer was postponed indefinitely by PANTEX staff. Thus, field testing at this location was not completed.

\section{Impacts of Current Practices}

\section{G.W.R. Endres}

The purpose of this task is to conduct basic studies that affect beta dosimetry and to develop methods of calculating energy deposition from beta radiation. This task also serves to identify beta dosimetry problems within the DOE community and to provide guidance to DOE.

A study of current practices was initiated, with emphasis given to those locations where gross fission products and uranium are handled. Installation of the Monte Carlo computer code EGS4 was delayed. A review of the DOE "Tiger Team" findings concerning beta problems was identified as a source of information relevant to this task. A meeting was held with key DOE staff members within the DOE community to discuss the needs and problems at facilities throughout the DOE community, and arrangements for tours of these problem sites were discussed.

\section{References}

Merwin, S. E., and K. L. Swinth. 1989. "Performance of an Exoelectron Dosimetry Badge for Personnel Beta Dosimetry. "Radiat. Prot. Dosim. 28(3):219-222. 
. 


\title{
Health Physics Support and Assistance
}

\author{
Project Managers: K. L. Swinth and J. M. Selby
}

This project focuses on identifying needed improvements in occupational radiation programs and measurement technologies, and on analyzing the applicability and impact of standards, regulations, and engineering or administrative actions on the U.S. Department of Energy's (DOE's) occupational radiation protection programs. This is accomplished by means of special technical studies. Technical assistance is provided in developing guidelines for implementing standards and regulations and in conducting and preparing technical reports as requested by the sponsor. This assistance also includes transferring laboratory-developed techniques to the field by means of DOE-sponsored workshops. Project objectives are achieved using the capabilities and expertise of Pacific Northwest Laboratory (PNL), other DOE laboratories, universities, and private industry. Progress made during FY 1990 on the Health Physics Support and Assistance (HPS\&A) tasks is discussed in the following subsections.

\section{Special Studies}

\section{J. M. Selby and K. L. Swinth}

The objectives of this task are 1) to provide technical assistance with development of guidelines for implementation of standards and regulations, and 2) prepare technical reports and conduct special studies for DOE-EH, as requested by the sponsor. Work and special studies performed in FY 1990 are described in the following sections.

\section{Neutron Quality Factor: L. G. Faust}

Both the International Commission on Radiological Protection (ICRP) and the National Commission on Radiological Protection (NCRP) are reaffirming their position that the Quality Factor (Q) for fast neutrons should be increased to 20 and the Quality Factor for thermal neutrons be increased to 5 . This is exactly what the DOE committee recommended 4 or 5 years ago--that $Q$ be increased by a factor of two unless energy spectra are available. If energy spectra are available, then $Q$ can be adjusted accordingly. As a result of discussions held with the other three members of the $Q$ committee it was decided that the report should be updated and perhaps published as a formal report.

\section{Annual Radiation Exposure Report: S. E. Merwin}

The draft 21st annual exposure report (CY 1988) was completed and sent to DOE for review in June 1990. Following a meeting with headquarters staff, it was determined that major revisions to several sections of the report were necessary before it could be published. The second draft of the report was sent to DOE Headquarters for review in September. The report contains considerably more information than has been included in past reports. In addition to the usual information, the draft includes sections on exposure scenarios, lifetime exposures, reportable radiation exposure incidents, risk, and the DOELAP accreditation studies. The draft also includes data that has never before been available, including doses by age, sex, occupation, and type of radiation.

\section{Lifetime Dose Study: R. J. Traub}

This task represents the initiation of a study of the external radiation doses received by workers employed at a large DOE facility. Dosimetry data was available for the years 1944 to 1984 at the study facility.

Graphical analyses were performed in order to become familiar with the data base, its extent, and its limitations. The data base was able to distinguish between the radiation dose received while employed at the facility and that received elsewhere, the latter dose was called "offsite dose."

The first analysis was to plot the maximum radiation dose at the age of last exposure for all workers in the data base. Males have accumulated radiation dose at a rate greater than have females (by about a factor of four). These data also show that only rarely do radiation workers exceed an accumulated dose of "(Age - 18) * 2 rem." These data included offsite radiation doses. The second analysis was to indicate the maximum cumulative 
radiation dose for the most highly exposed individuals as a function of the duration of monitoring. Results indicate that the most highly exposed individual at the study facility accumulated radiation dose at a rate of 2.14 rem per year.

In order to make certain inferences about the radiation doses received by radiation workers, it is necessary to determine the statistical distribution that describes the data. Radiation doses have been assumed to be described by the log normal distribution. However, for radiation doses to follow the log-normal distribution would imply that there is always some finite, albeit small, probability of large radiation doses. Plots of data have indicated that within the acceptable dose range the radiation doses do indeed follow the log-normal distribution, but that at higher doses (those that approach the upper dose limits) the slope reduces, indicating an aversion to the higher doses. Because of the ALARA doctrine, this dose aversion induced departure from linearity begins at lower doses with passing years. Consequently, the value of the lognormal distribution to estimate the median radiation dose (which generally occurs at very low levels) is reduced. Hybrid Log-Normal analysis software was used to plot data for the years 1974, 1979, and 1984. These data indicate that the Hybrid Log-Normal distribution is a useful statistical tool for analysis of radiation exposure data.

The final analysis was to determine whether the radiation dose received at the study facility was influenced by the age of the individual receiving the exposure. These data have not been quantitatively analyzed. However, plots of the data do not indicate any trends that would indicate that age is a consideration.

The analyses performed to date indicate that the most highly exposed radiation workers accumulated radiation dose at a rate of about 2 rem per year. The numerical value of 2 rem per year is valid when considering both years of age and years of monitored work. The data also indicate that there is a difference between males and females in the rate of dose accumulation; males have accumulated radiation dose at a rate four times that of females. Also, analyses limited to visual inspection of plotted data do not indicate gross age discrimination with regard to dose accumulation. Finally, the Hybrid Log-Normal distribution appears to adequately describe the distribution of radiation doses among workers at the study facility.

\section{Contamination Measurement Technology:} J. R. Johnson

A final draft document on allowable levels of tritium contamination on surfaces was distributed to the review committee. The report reviews the hazards of tritium surface contamination and recommends relaxation of current limits. All comments on the Tritium Surface Contamination draft report received will be considered during the revision of the draft report. The report will be revised and distributed in October 1990.

\section{Radiological Technical Support to DOE-EH: C. M. Stroud}

Direct technical support by a staff member assigned to DOE-HQ included facilitation of communications between PNL and $\mathrm{HQ}$, technical review of documents, and assistance in developing coordinated project tracking tools. Substantial efforts were expended in the review of technical issues associated with SARs, Action Plans, Standards and Regulatory Guides, etc.

BEIR-V Analysis: J. M. Selby, R. J. Traub, J. K. Soldat, and S. E. Merwin

The BEIR-V report was reviewed for DOE/HQ to evaluate the potential impact on DOE if the study's findings are adopted in regulations. An early assessment of the report identified seven items of concern and was used to assist in preparation of a questionnaire for DOE facilities. Responses will assist in evaluating the impact of any changes in regulations based on the BEIR-V report. A special analysis of exposure data was completed for inclusion in a report to the Secretary of Energy, and specific exposure data were provided to DOE on several occasions as requested. The data were used to support the assessment of the impact of the BEIR-V report on DOE.

Special Studies Per DOE Request: J. M. Selby and K. L. Swinth

The following special studies were conducted during this fiscal year. 
- Prepare Exposure Scenarios - Exposure scenarios for several types of DOE facilities were prepared and sent to DOE-EH.

- Review Implementation of 5480.11 - A quick analyses of exposure data for 1977,1979 , and 1987 was prepared to use in responding to questions on the cost of implementing 5480.11 and doubling the quality factor, $Q$, for neutrons.

- 1-129 Detection Limit - A letter report was prepared on the minimum detectable amount (MDA) of ${ }^{129}$ that is achievable counting "smear samples" collected from contaminated surfaces.

- Quality of REIRS Data - A draft analysis of problems encountered with the CY 1987 exposure data sent to REIRS was provided for use by DOE-EH in discussing reporting problems with the field offices.

- SAR Review - Three chapters of the Savannah River Plant tritium facility safety analysis report were reviewed and comments provided to $\mathrm{HQ}$.

- EPA Rule Review - The proposed EPA Rule "Prevention of Significant Deterioration for Particulate Matter" was reviewed for potential impact on DOE facilities.

- Review Environmental Assessment - Health physics aspects of the Environmental Assessment of NTS Area 5 were reviewed and comments provided to $\mathrm{HQ}$.

- Critique of Performance Indication Program -A critique of the draft DOE performance indicator program was provided to $\mathrm{HQ}$. The critique pointed out several areas of concern based on staff experience with DOE facilities and experience with the related Nuclear Regulatory Commission programs.

- Collection of Historical Data on Exposures Historical exposure data were prepared in a requested format and provided to $\mathrm{HQ}$.

- Loan of Phantom - Coordination was provided for the loan of a PNL phantom to the International Atomic Energy Agency (IAEA) for use in analysis of counting results from the Chernobyl incident.
- Whole Body Counting Paper - A short paper on whole body counting for ${ }^{60} \mathrm{Co}$ was prepared for headquarters staff.

- Non-Uniform Skin Irradiation - Comments were provided on an effort proposed by Oak Ridge National Laboratory (ORNL) to develop methods for beta dose determination from nonuniform skin irradiation.

- Administrative Exposure Limits - A technical review was performed on a request for contractors to review administrative exposure control limits at their facilities against guidelines provided by headquarters.

- Information on Uranium Effects - Background information was collected for DOE on the effects of uranium on humans and/or animals.

\section{Standards}

\section{J. M. Selby and K. L: Swinth}

The purpose of this task is to provide DOE-EH with technical resources for the timely review of proposed standards and recommendations. This effort will include preparing draft responses, historical perspectives, and supporting documents.

Reference Man Data Base: R. J. Traub, K. F. Eckerman, and M. Cristy

A data base of journal articles, reports, books or book chapters, and other literature has been developed to support the work of the Task Group on Revision of Reference Man, a task group formed by Committee 2 of the International Commission on Radiological Protection (ICRP) to revise, update, and expand ICRP Publication 23 on Reference Man, published in 1975. The task group is including more data on women, children, and the fetus because of the focus on protecting the public as well as potentially pregnant and other female radiation workers. An Asian Reference Man is also being developed, which will be included as an appendix to the report.

The data base comprises 1) hard copy of all publications collected and 2) a computer data base using dBase III-plus software that includes searchable fields for bibliographic information, 
keywords developed specifically for this project, and abstracts. At present, the data base has 2455 hard copies. The computer database has bibliographic information on 2412 documents; keywords have been entered for 2350 of these and abstracts for 2375 .

Internal Dosimetry Standards: D. R. Fisher, A. C. James, and J. R. Johnson

The purpose of this task is to achieve the following: 1) contribute to and monitor the progress of NCRP and ICRP scientific committees dealing with occupational internal dosimetry methods, models, and parameters; 2) ensure that recommended or state-of-the-art biokinetics models for the respiratory tract, skeleton, liver, kidneys, and other organs are incorporated into computer codes used for internal dosimetry at DOE facilities; 3 ) provide a bridge between developments in biological research under DOE/OHER and applications to worker safety under DOE-EH; and 4) provide review of ICRP and NCRP internal emitter standards for DOE-HQ.

Staff members participated in the Third International Workshop on Respiratory Tract Dosimetry, July 1-3, 1990, in Albuquerque, New Mexico, presenting four papers and co-authoring two others at the workshop (see Publications and Presentations). The progress of both the ICRP and the NCRP task groups on respiratory tract modeling was presented at the workshop. A letter report was prepared for DOE-HQ on the proposed changes and potential impacts on DOE operations of revisions to ICRP and NCRP respiratory tract models. Acceptance of the task group report by the ICRP will require substantial revision in secondary limits (i.e., allowable limit intake (ALI) and derived air concentration standard (DACS) for inhaled internal emitters) for radiation protection.

NCRP SC 46-10 on Assessment of Occupational Dose from Internal Emitters continued its work on the first draft of a new report. It appears that the NCRP will recommend against the requirement to record and report the annual effective dose equivalent. This could affect current DOE Orders dealing with assessment of internal doses.

Review and Analysis of Proposed Standards: J. M. Selby, R. J. Traub, and K. L. Swinth

Radiation protection instrumentation standards ANSI N42.17A, B, and C are being developed to form the basis for an instrumentation testing program. The first standard was published in November 1989. The remaining two were published early in 1990.

A meeting of the IEC SC45B standards committee on radiation protection instrumentation was held in Sicily in December 1989 and attended by PNL staff. Several standards under development, including one on the total dose meter (developed by DOE-EH research), are of direct interest to DOE-EH.

A comprehensive review of the draft revision of ICRP-26 (ICRP/90/G-01) was completed for HQ. The commission continues to push for committed dose rather than an annual effective dose equivalent as adopted in the U.S. This could have an impact on DOE operations. Similarly, the addition of $1 \%$ of the skin and extremity dose to the effective dose equivalent will impact DOE operations, particularly at weapon facilities.

ANSI N43.3, "General Radiation Safety Standard for Installations Using Non-Medical X-Ray and Sealed Gamma-ray sources up to $10 \mathrm{MeV}^{,}{ }^{\prime}$ was reviewed at the request of DOE. An NCRP draft document on calibration of radiation protection instruments was reviewed and comments were provided to $\mathrm{HQ}$. This report provides a general description of health physics instrument calibration considerations and techniques.

The ISO ad hoc working group on radioactivity measurements, which became Working Group 2 of ISO TC85, met and will be developing a series of standards on radioactivity (contamination) measurements associated with materials for reuse, recycle, or disposal as nonradioactive waste. J. M. Selby is a member. K. L. Swinth attended an ISO subcommittee meeting (Technical Committee 85, Subcommittee 2) in Móscow, Russia, as acting head of the U.S. delegation.

\section{Health Physics Guidance Documents}

\section{K. L. Swinth}

The purpose of this task is to develop guidance standards that adequately captures requirements in DOE Orders (specifically DOE Order 5480.11) and guide facilities in implementing health physics practices that will improve performance in worker protection. Several documents are being prepared: 
Guidance Document for Tritium Facilities: J. B. Martin

Review comments are being incorporated into the PNL chapters of the draft "Guide to Good Practices at DOE Tritium Facilities." Mound Lab is working on resolution of comments on the other chapters of the document. The manual will provide guidance in conducting safe operations with tritium at DOE facilities.

Handbook and Field Guidance for DOE Health Physicists: K. L. Swinth, D. P. McCarthy, and M. H. Chew (M. H. Chew and Associates)

A new outline reflecting the decision to split this effort into two tasks was submitted to DOE-EH. A comprehensive handbook of data will be prepared and a field guide will be developed using information from the handbook. A considerable amount of data has been collected and sorted. The handbook will provide general radiation protection information, rules of thumb, reference data, and information specific to radiation protection at $D O E$ facilities.

DOE Standard for X-Ray Generating Devices and Gamma-Ray Sealed Sources: J. M. Selby and J. G. Stephan

A DOE standard is being drafted that describes requirements and provides guidance for DOE and contractor users of $\mathrm{x}$-ray generating equipment and gamma-ray sources. The standard includes, among others, DOE requirements for 1 ) the use of radiation devices and sources used in the DOE complex for industrial applications, 2) design of industrial installations, 3) pre-operational and operational surveys and survey instruments, 4) operations, 5) training, and 6) administrative control.

To adequately respond to comments made by DOE-HQ, additional technical work will be required. The draft standard is scheduled to be reviewed by a working group composed of qualified experts from several DOE sites.

\section{DOE Radiation Safety Training Manual: \\ P. C. Olsen}

DOE Orders 5480.11 and 5480.6 require specific radiation safety training be given to all $D O E$ occupational and radiation workers, and radiation protection technicians. A draft document on radiation safety training requirements for the $D O E$ work force has been developed to identify each learning objective to be used in a performance-based training program for DOE contractors. Minimum generic training criteria are set forth that meet the requirements of DOE Orders and establish a comprehensive base of radiation protection training that will provide the basis for safe and effective radiation protection programs at DOE facilities.

To encompass radiation safety training for different facility types, several specific supplemental training modules have been developed for the following DOE facility types: plutonium facilities, uranium facilities, tritium facilities, and accelerator facilities. These additional training modules tailor the generic radiation safety topics to a particular DOE facility type where it has been determined that additional safety information must be imparted in order to maintain an effective training program.

\section{Calibration Guidance Documents: $K$. L. Swinth}

An outline of a calibration training course was submitted to DOE-EH on special request. This source would provide comprehensive training of DOE-EH personnel in all aspects of radiation instrument calibration and use.

The original ANSI N323 standard on instrument calibration was revised and prepared as a comment draft for the standards committee. An outline for the calibration guidance manual was submitted to DOE-HQ.

Preparation for a calibration accreditation program for DOE-HQ focused on developing a philosophy and estimating the cost of operating a program. It appears that establishing two laboratories that interact directly with the National Institute of Standards and Technology (NIST) and in turn service the remaining DOE facilities will meet the needs of DOE. The two laboratories would operate as secondary laboratories under the National Voluntary Laboratory Testing Program (NVLAP) program for calibration. A meeting of federal laboratories representatives was attended to complete the technical criteria for the NVLAP program and to complete key portions of the operational criteria. This program should be in operation early in CY 1991. The remaining DOE 
laboratories would operate as tertiary facilities and interact with the secondary laboratories. These procedures must be developed; however, a model exists within the Health Physics Society (HPS) accreditation program.

Calculational studies were performed on typical calibration source geometries to study the effect of scatter. This is important since the accreditation programs require a knowledge of the scatter fraction and this is not known for most calibration geometries used in DOE. The calibrations "freein-air" indicate a scatter contribution of $14 \%$ at 2 meters. This compares with $17 \%$ for an ISOrecommended irradiator and $33 \%$ for a commercial irradiator. In a source well at 2 meters the scatter fraction is $52 \%$. In the latter two cases tests have shown that design changes can reduce the scatter to near the $17 \%$ value. The well geometry provides the most practical routine calibration geometry and with the design changes under evaluation it should meet the secondary laboratory criteria. Preliminary data from this study were presented at the annual HPS meeting.

\section{Radiation Protection Guidance for DOE Facilities: $M$. H. Chew Associates}

The final version of the Radiation Protection Guidance document was delivered to DOE-HQ. This document provides general radiation protection guidance for DOE facilities and complements many of the specific standards and guidance documents in preparation.

\section{Health Physics Reviews and Technical Assistance to Office of Safety Policy and Standards (OSPS)}

\section{K. L. Swinth}

The objective of this task is to provide technical support to DOE-EH in performing health physics reviews, analyzing weaknesses and strengths in DOE radiation programs, identifying needed changes or additions to orders, and identifying guidance documents needed to strengthen or further enhance the programs.

\section{Health Physics Reviews: L. H. Munson}

The Radiation Protection Review Program appraisal document was revised, at the request of $\mathrm{DOE}-\mathrm{EH}$, to incorporate nonionizing radiation. $A$ revised draft was sent to DOE-EH early in the fiscal year. Additional direction was provided by DOE-EH and the manual was expanded to include additional sections covering areas peripheral to radiation protection but directly important to it. Revision 3 of the document with these changes was submitted to headquarters for further review and comments.

\section{Nonionizing Radiation Guidance:}

J. A. Leonowich

A report detailing the status of nonionizing radiation (NIR) protection in the DOE complex was forwarded to headquarters. The report detailed the results of a number of site visits to DOE sites over six months. The main conclusion was that NIR protection programs throughout the complex require further guidance from headquarters in order to be effective.

A DOE standard on nonionizing radiation was completed. It includes sections on microwaves/ radiofrequency, lasers, extremely low frequency (ELF) fields, magnetic fields, and ultraviolet. 


\title{
Internal Dosimetry and Measurement Upgrade
}

\author{
Project Managers: L. G. Faust and D. R. Fisher
}

The Internal Dosimetry and Measurement Upgrade Project is a multilaboratory research effort to improve internal dose assessments at U.S. Department of Energy (DOE) and DOE-contractor laboratories. Internal dosimetry is the science of determining radiation doses to organs and tissues from internally deposited radioactive materials. It includes the analysis of inadvertent or chronic low-level intakes of radioactive materials by workers; analysis of the redistribution of radionuclides in body fluids, tissues, and organs; and analysis of the excretion of radionuclides from the body. Estimating intake also involves measurement of radionuclides in the body by external counting and measurement of radionuclides in bioassay samples. Internal doses are calculated from estimated intakes using biokinetic models.

Quality assessments of internal dose are required by DOE orders. Studies to improve the methods of internal dose assessment are in progress at the Pacific Northwest Laboratory (PNL) and at other supporting DOE laboratories and universities. The following section describes progress made during fiscal year (FY) 1990 on the major task.

\section{Software Package for Occupational Internal Dosimetry}

\author{
D. L. Strenge, R. A. Peloquin, J. R. Johnson, \\ D. R. Fisher, and M. J. Sula
}

PNL staff developed and distributed a muchneeded software package for assessing internal radiation exposures that may occur when workers inadvertently inhale, ingest, or are punctured with radioactive materials in the work place. Internal radiation doses usually cannot be measured directly, and therefore these doses must be calculated using mathematical models describing the complicated characteristics of radionuclide metabolism and transport through the body.

The software, called CINDY (Code for INternal Dosimetry, was prepared at the request of the DOE for use at DOE and DOE-contractor nuclear facilities. It was designed specifically to meet the new and more stringent requirements of DOE Order 5480.11 (DOE 1989), EPA guidance to federal agencies, and current national and international scientific recommendations for performing internal dose calculations. Included in the software package are the computer code, user interface, data libraries, and differential equation solver. The documentation includes an installation guide and a two-volume user's manual. More than 40 potential users at DOE facilities were involved in the design and implementation of CINDY. Code design and features were evaluated by an external peer-review team consisting of four internationally recognized experts in internal dosimetry: Prof. John Poston (Texas A\&M University), Prof. Kenneth Skrable (University of Lowell), Dr. Keith Eckerman (Oak Ridge National Laboratory), and Dr. Rick Brake (Los Alamos National Laboratory).

The CINDY code provides a powerful new tool for improving the quality and uniformity of internal dose assessments at DOE and DOE-contractor facilities. It includes current International Commission on Radiological Protection (ICRP) and National Council on Radiation Protection and Measurement (NCRP) biokinetic models and model parameters for radionuclides encountered in the work place. It also contains other scientific models for specific radionuclides and chemical compounds, and provides the user with the option of using an ICRP model, other specific model, or a user-developed custom model. Future respiratory tract models and other changes necessitated by scientific development will be incorporated as required to serve the needs of the DOE community.

The CINDY code models any combination of radionuclide intake by inhalation, ingestion, and direct injection or absorption. Exposures may be acute or chronic, and consist of different chemical 
solubility classifications. The multiple intake option (i.e., intakes at more than one time) is not yet implemented.

The software provides new capabilities for interpreting bioassay data (such as urinalyses and whole-body counting) and for estimating the radionuclide intake at the time of exposure. It will also aid in the design of bioassay monitoring programs. It allows users to calculate organ dose equivalent, annual effective dose equivalent, and committed effective dose equivalent (for materials retained for long periods in the body), as now required by DOE orders. Future versions may be designed to meet the specific needs of commercial nuclear power plants, industrial facilities, hospitals, and universities where the potential exists for radioactive materials to be taken into the body.

Four operating modes were included in version 1.0:

- Intake Assessment Mode (to estimate intakes based on bioassay data using weighted or unweighted least-squares regression between measured and expected bioassay values calculated, based on reference man or other models)

- Dose Assessment Mode for Specified Time Periods (to estimate organ dose equivalents and effective dose equivalents for specified time periods and the 50-yr committed effective dose equivalent for known intakes)

- Dose Assessment Mode for Calendar Year Doses (to estimate organ and effective dose equivalents for the present calendar year and future annual increments for specified intakes)

- Bioassay Projection Mode (to estimate organ burdens and urinary and fecal excretion rates from given intakes)

Reports of calculational results may be customized to the specific requirements set forth by each user facility's internal dosimetry program. PNL will continue to provide code quality assurance, quality testing, maintenance, and revision and update services for all users. Future revisions of the code will be issued as biokinetic models, dose factors, and user capabilities are updated.

\section{Reference}

U.S. Department of Energy (DOE). 1989. Radiation Protection for Occupational Workers. DOE Order 5480.11, Washington, D.C. 


\title{
Laboratory Accreditation Support Program
}

\author{
Project Managers: J. C. McDonald and J. M. Selby
}

The purpose of this program is to identify and support the development of improved calibration and measurement accreditation technology for radiation protection. This is accomplished by publishing procedures manuals for use in radiological protection programs, upgrading the testing methods to be employed by Department of Energy (DOE) laboratories and processors, investigating new concepts and techniques to keep current with new standards and guides, and by operation of a reference calibration laboratory to support radiological calibrations at other DOE laboratories.

\section{External Dosimetry Accreditation Development}

\section{J. C. McDonald and R. Harty}

The purpose of the External Dosimetry Accreditation Development Task is to develop and improve proficiency testing techniques and categories for the DOE Laboratory Accreditation Program (DOELAP).

Three subtasks represent the three major areas of accreditation program development: extremity dosimetry testing, accelerator dosimetry testing category, and new guidance for the DOELAP whole-body dosimetry testing program.

\section{Extremity Dosimetry: R. Harty}

The performance testing study was completed, and the results were published in September. Data were obtained from seven DOE contractor facilities that participated in the performance testing study. The ring dosimeters submitted for testing passed $58 \%$ of the time at the tolerance level specified in the draft standard. The wrist dosimeters passed $55 \%$ of the time. The results indicated a need to incorporate performance testing of extremity dosimeters into DOELAP to ensure that DOE facilities appropriately measure extremity dose. The results also indicated several areas where changes were needed in the draft standard used for testing, which was written by the Health Physics Society Standards Committee.

The draft standard for performance testing of extremity dosimeters was revised based on the results obtained during the performance testing study, as well as on comments received from participating facilities. A committee of nine people from eight DOE or DOE contractor facilities was organized to review and comment on the revised draft standard,

The DOE Extremity Working Group met twice during FY 1990. The working group members discussed potential changes to the draft standard, and a revised draft is currently being rewritten to reflect the working groups comments and conclusions. Revisions to the draft standard include the testing categories, the test ranges, and the performance criteria.

A presentation on the draft standard was given at the Health Physics Society Annual Meeting in Anaheim, California, June 24-28. A presentation of the performance testing results was given at the Ninth Panasonic International Symposium in Keystone, Colorado, June 18-22.

\section{Accelerator Dosimetry: J. C. McDonald}

The DOELAP program has established a proficiency testing protocol for the personnel dosimeters issued to most DOE workers. However, the radiation sources used for these tests are not appropriate for the radiation environment within DOE high-energy accelerator facilities. This subtask is concerned with the development of a method to test the proficiency of dosimeters used in accelerator facilities.

During FY 1990, a meeting of health physicists at major DOE accelerator facilities was held at the annual Health Physics Society meeting in Anaheim, California, on June 25, 1990. The topic discussed was the feasibility of conducting a dosimetry intercomparison among accelerator facilities. The reason for investigating such a 
program is based on the fact that the National Institute of Standards and Technology (NIST) cannot provide calibrations for high-energy neutrons. The accelerators themselves are the most appropriate sources of high-energy neutrons, and an intercomparison would make use of exposures at the various facilities. A list of volunteers was collected at the meeting; and this group will provide input to help develop the program. In addition, a letter report describing the proposed program was written.

\section{New Guidance for DOELAP Whole-Body Dosimetry: J. C. McDonald}

The DOELAP standard for proficiency testing of personnel dosimeters, DOE/EH-0027 (DOE 1986), which has been in use for nearly five years, contains a recommendation that it should be periodically reviewed and updated. A five-year review period is considered to be appropriate because other standards such as those issued by the American National Standards Institute (ANSI) are reviewed every five years. In preparation for this review, several major aspects of the standard have been studied, including the use of new operational quantities, the addition of categories for high energy photons, thermal neutrons and beta slab sources, and a new assessment of uncertainties. A draft report on the potential impact of the International Commission on Radiation Units and Measurements (ICRU) operational quantities on DOE dosimetry and instrument calibrations was prepared, and an updated draft of the DOELAP Long-Term Plan was also prepared.

\section{Calibration}

\section{J. C. McDonald and M. K. Murphy}

Radiological calibration is fundamental to radiation protection. The quality of a radiation protection program depends on maintaining standards for radiological calibration that are accurately traceable to national standards and routinely verifying the precision of the calibration measurements. Intercomparison is necessary to improve accuracy, uniformity, and precision in the measurement of radiological standards.

\section{Radiological Calibration Intercomparison: M. K. Murphy}

The objectives of the intercomparison program are to 1) provide standard measurement techniques that allow DOE laboratories to assess and improve the accuracy of radiological calibration sources, 2) provide a basis for recommending improvements in calibration techniques and units generally applicable to all DOE facilities, and 3) provide a forum addressing existing and potential problems related to radiological calibrations by holding periodic workshops.

Of the ten participants in the program who were scheduled to contribute in FY 1990, seven have performed measurements with the instrument sets and one has performed measurements with the secondary standard beta source set provided. The new extrapolation ionization chamber arrived in September. The superior sensitivity of this chamber, which is to be included in the instrument set of low activity beta sources, will make an important contribution to the program.

The desirability of incorporating a self-contained neutron dose rate meter into the instrument set for measuring dose rates from neutron sources was studied. Including this meter would be useful if it proved to give consistently accurate readings over a long period of time. We should be able to acquire an instrument with the required stability. Neutron intercomparison measurements would be greatly improved by the convenience, compact size, and simplicity of operation of this instrument.

\section{Radionuclide Phantom Intercomparison: P. C. Olsen}

The purpose of this task is to compare the measurement performance and intercalibration abilities of two different in vivo bioassay wholebody counting phantoms. This is necessary for the anticipated initiation of in vivo laboratory pilot accreditation testing which will be administered by Radiological and Environmental Sciences Laboratory at Idaho National Engineering Laboratory, and for current intercalibration capabilities being considered on a national basis with NIST.

The abilities of two phantoms to perform and to closely simulate human response to radionuclide depositions in the systemic tissues were compared. Additional measurements have been made on the europium-antimony poly bottle phantom. Additional research on actual human deposition measurements is being pursued in order to correlate data from the two phantom types with human data. 
In parallel with this task is the development of lung inserts for use in chest counting phantoms that will be used by Radiological and Environmental Science Laboratory (RESL) for pilot accreditation testing. Preliminary testing of the insert material has been completed, and the results are being evaluated. A complete set of procedures for manufacturing the inserts and then measuring activities in the lungs will be developed.

\section{Bioassay Laboratory Accreditation P. C. Olsen}

A proficiency testing and accreditation program is being developed for bioassay measurements conducted in DOE facilities. This has involved evaluating the suitability of ANSI Standard N13.30, "Performance Criteria for Bioassay." A DOE standard for proficiency testing and accreditation is also being developed to reflect the needed changes based on the results of the testing program. The procedures for this proficiency testing program and accreditation will be conducted at RESL. PNL will continue to provide technical assistance and scientific development support for this accreditation program.

A polyurethane lung phantom material is being developed that will allow incorporation of a larger quantity of $\mathrm{H}_{2} \mathrm{O}$ into the lung. The new slabs were tested for gamma interaction properties and electron density and trace element composition.

A defective piece of equipment has delayed the production of the lung sets. Production has been rescheduled, and the torso phantom to be used in the pilot accreditation will be tested.

\section{Instrumentation Testing and Accreditation}

\section{K. L. Swinth}

The purpose of this task is to determine the feasibility of an instrumentation testing program, and to develop procedures, standards, and plans DOE needs to conduct such a program. Portable radiation protection instrumentation presently employed in DOE facilities lacks the desired reliability, accuracy, and precision to meet current measurement needs. This program will provide a means for both evaluating and improving DOE instrumentation programs.
Preparations for an instrument testing program within DOE included study of the philosophy of instrument testing, testing requirements, and methods of operating a DOE program. Testing was completed on the prototype Department of Defense (DOD) alpha survey meter and the beta survey instrument prototype. Selected instruments were also tested to the full set of ANSI N42.17A requirements.

The standards ANSI N42.17B, "Performance Specifications for Health Physics Instrumentation Occupational Airborne Radioactivity Monitoring Instrumentation" and ANSI N42.17C, "Performance Specifications for Health Physics Instrumentation Portable Instrumentation for Use in Extreme Environmental Conditions," were published in March.

\section{Special Assignments}

\section{J. C. McDonald}

This task was established to allow for a quick and efficient response to issues that must be acted upon promptly. Potential solutions for issues that develop in the field are developed and documented in letter reports. This task also provides the degree of flexibility that is necessary to respond to changing programmatic directions.

Information was provided on a potential change in the calibration phantom to be used in a new draft ICRU report, International Standards Organization (ISO) standards, accelerator dosimetry, and angular response of dosimeters.

A study was undertaken to identify interim conversion factors to calculate extremity neutron dose equivalent from neutron fluence. Monte Carlo computer calculations were performed to determine these conversion factors for extremities and extremity phantoms exposed to unmoderated and $\mathrm{D}_{2} \mathrm{O}$ moderated ${ }^{252} \mathrm{Cf}$ sources.

\section{Internal Dosimetry Accreditation}

\section{R. Fisher}

The purpose of this task is to develop the proficiency testing procedures for the accreditation of internal dosimetry programs at DOE facilities. 
An outline of the accreditation program was written into the draft Performance Standard for Internal Dosimetry Programs as Section 9.0. Threemember internal dose scientific committees are proposed for each radionuclide category to develop testing scenarios for laboratory accreditation.

A draft manual of DOE procedures for performance testing of internal dosimetry programs was completed and submitted to DOE-HQ for review and comment. This manual provides procedures for conducting the accreditation of internal dosimetry programs at DOE facilities. It follows guidance previously issued in the draft Performance Standard for Internal Dosimetry Programs.

\section{Criteria for Fecal Bioassay}

R. L. Hill and D. R. Fisher

The purpose of this work is to prepare guidance for use at DOE and contractor facilities to address the appropriate implementation of fecal bioassay procedures for internal dose assessment.

A draft document on criteria for fecal bioassay was initiated and submitted to DOE-HQ and members of the Expert Group on Internal Dosimetry for review and comment.

\section{Reference}

U.S. Department of Energy. 1986. Standard for the Performance Testing of Personnel Dosimetry Systems, U.S. Department of Energy, Washington, D.C. 


\section{Neutron Dosimetry Evaluation and Upgrade}

\section{Project Managers: L. G. Faust and J. A. Leonowich}

The U.S. Department of Energy (DOE) Neutron Dosimetry Evaluation and Upgrade Project has two primary objectives: 1) to assess current personnel neutron dosimeter capabilities, and 2) to develop improved personnel neutron dosimeters and instrument systems. The project provides DOE with an assessment of the current status of personnel neutron dosimetry capabilities at DOE facilities, develops improved near-term personnel neutron dosimetry techniques, and develops concepts with the potential for a significant technical breakthrough in state-of-the-art personnel neutron dosimetry and instrumentation. Technology transfer meetings and workshops are conducted to make any advances available to DOE contractors and private industry. Research and development activities are conducted at Pacific Northwest Laboratory (PNL) and several supporting DOE laboratories, universities, and private companies in order to involve the expertise of the most appropriate organizations and individuals on the task of improving operational neutron dosimetry and radiation protection in the field.

The project has identified significant problems in the field determination of personnel neutron dose and dose equivalent and in the ability to comply with applicable DOE Orders and regulations. Where appropriate, improved dosimetry techniques are developed for implementation at DOE facilities. The following subsections describe progress made during FY 1990.

\section{Field Neutron Spectrometer}

\section{W. Brackenbush, R. I. Scherpelz, and}

\section{J. L. Thorngate (LLNL)}

All existing neutron dosimeters and survey instruments exhibit some energy dependence, i.e., the response per unit of dose equivalent changes with neutron energy. Various national and international advisory bodies have proposed increasing the quality factors for fast neutrons. Thus, there is a need for neutron spectrometer systems that can be used in the work place to improve the accuracy of existing neutron dosimetry and help estimate the impact of proposed changes in radiation protection standards.

The Department of Energy continues a program to develop transportable neutron energy spectrometers that can be used by health physicists to measure the neutron energy spectra in the work place. Work at PNL concentrated on developing a transportable neutron energy spectrometer from commercially available components in a relatively short time; long-term efforts focused on work at Lawrence Livermore National Laboratory (LLNL) for development of a portable liquid scintillator spectrometer using proprietary electronic circuitry developed at LLNL.
PNL developed a "field neutron spectrometer" system that fits into a suitcase for ease of transport. This system is based on laptop personal computers used to control the acquisition and analysis of spectral data in the field. Because no single type of spectrometer is adequate over the entire range of energies found at DOE facilities, the field spectrometer uses a variety of detectors:

- tissue equivalent proportional counters to measure the absorbed neuron dose and provide estimates of quality factors

- helium-3 proportional counters to provide high resolution energy spectra between $100 \mathrm{keV}$ and $3 \mathrm{MeV}$

- multisphere or Bonner sphere spectrometers to provide low resolution spectra over an energy range extending from thermal to over $20 \mathrm{MeV}$.

Improvements were made this year to make the unit more reliable during power line transients, to make the unit easier to operate, and to allow the unit to be used at dose rates below $1 \mathrm{mrem} / \mathrm{h}$. Extensive field tests demonstrated successful operation over a 3-month period at the Plutonium 
Finishing Plant. A report describing the addition of the multisphere spectrometer has been prepared. The "suitcasen unit is now available from a commercial vendor, so that costs are reduced, and the unit can be more widely used.

Work at LLNL is progressing on developing a truly portable, battery-powered spectrometer using a liquid scintillator detector and proprietary electronics being developed at LLNL. Work has progressed on developing pulse shape discrimination circuitry to separate neutron and gamma induced events in the liquid scintillator and on developing a stable light pulser used to regulate the gain of the unit with changing temperatures. Work also progressed on the development of a DC-to-DC high voltage converter circuit to power the photomultiplier. The high voltage can be regulated by observing the output from the light pulser, so that the overall gain of the system can be closely controlled.

During FY 1990, work was completed on the design, breadboard testing and computer-aided circuit design for printed circuit boards for the pulse shape discriminator, light pulser and HV supply. Work in FY 1991 will concentrate on development of suitable low power, analog-todigital converters (ADCs) using successive approximation or flash ADCs to replace conventional Wilkenson ADCs.

\section{Total Dose Meter}

\section{W. Brackenbush}

With the completion of the final report, work was completed on the "total dose meter," a small, battery-powered instrument to determine the dose equivalent in mixed neutron and gamma radiation fields. The total dose meter has evolved into a small instrument about the size of a portable, hand-held radio that can measure and record the radiation dose. A cylindrical tissue equivalent proportional counter measures the absorbed radiation dose, and a microprocessor estimates the dose equivalent and shows the accumulated dose equivalent on a liquid crystal display. The instrument contains two analog-to-digital converters to measure the distribution of neutron and gamma events in the tissue equivalent proportional counter, and the energy deposition spectra are stored in memory. A record of the absorbed radiation dose as a function of time can be transferred to a personal computer for further analysis.

\section{Combination Thermoluminescence/ Track Etch Dosimeter}

\author{
M. A. Parkhurst, D. E. Hankins (LLNL), and \\ S. Homann (LLNL)
}

The efforts during FY 1990 focused on the refinement of a procedure to improve the detection of the low energy range of fast neutrons and the completion of an automated readout system capable of providing track etch dosimeter (TED) track size distributions as well as track densities from neutron exposures. Other tasks included a search for alternate suppliers of high quality track detector material from the major international vendors and further research into the use of a dosimeter holder of polyethylene hemisphere to help reduce the angular dependence of the detector.

The boron radiator optimization task was completed and it was learned that a boron concentration of $35 \mu \mathrm{g} / \mathrm{cm}^{2}$ provided the best overall neutron response. As little as $11 \mu \mathrm{g} / \mathrm{cm}^{2}$, however, provides a significant improvement to the low energy neutron response over the standard polyethylene radiator. The remaining challenge in the manufacture of the boron radiators was to eliminate the striation patterns that usually were apparent in the radiator material. The University of Connecticut tracked the cause to a lattice structure in the Teflon-coated casting plates. They identified a Teflon coating with a smoother surface and successfully cast new radiators that show no striation. The radiator formulation and manufacturing processes are now ready for technology transfer. Promotional efforts to alert industry to the radiator formulation and its use in dosimetry have begun with the presentation at a professional meeting of polymer manufacturers. Further technology transfer plans are under way to target the specialty polymer manufacturers and the CR-39 vendors to provide the knowledge of radiator manufacture and increase the interest in its use for detection of intermediate energy neutrons. 
The track analysis-specific image analysis software developed at LLNL through this program has been written for use on an AT-compatible 386 computer. A manual is being written to assist the user on its procedures, capabilities, and limitations. In addition to track counts and area measurements, this software calculates track-size distributions automatically. PNL is testing the software to evaluate its ease of use before it is released to other DOE laboratories. A track recognition program will be interfaced to the image analysis program to help estimate neutron interaction energies from track-size distributions.

Continued implementation assistance to the other DOE laboratories has resulted in responses both at PNL and LLNL to numerous information requests. Several groups of new contractor personnel not involved in the original hands-on laboratory transfer seminars were provided opportunities to observe etching and readout procedures.

\section{Effective Dose Equivalent (EDE) System}

\section{J. E. Tanner, R. J. Traub, and R. D. Stewart}

During FY 1990, work centered on testing the calculational technique and completing a data library of organ dose equivalents for all the major geometries, energies, and for the male and female phantoms. A utility code was written to estimate the effective dose equivalent for a known spectrum of neutrons and source geometry using the monoenergetic data in the library.

The Monte Carlo neutron and photon transport code, MCNP, used to calculate the organ fluxes in the phantoms was upgraded to Version 3B. Version $3 B$ is the currently supported version at Los Alamos National Laboratory and it has many additional features that makes it much more useful than the older versions. Along with a multigroup capability, an electron transport capability, and a much more powerful and versatile source specification scheme, a tally plotting feature was added that allows the user to interactively produce plots of the results. This becomes very helpful when dealing with 96 energy groups for all the flux tallies.

Several modifications were made to the computer phantom models that serve as the input to MCNP. The red bone marrow regions were explicitly defined as well as the lenses of the eyes, and tallies for these were added to those for the skin of the whole body. With MCNP Version $3 B$ and the new input models, the organ fluxes were recalculated for the four standard geometries (AP, PA, LAT, and ISO), 14 discrete energies, and the male and female phantoms using the special $S(a, b)$ cross-sections for the low-energy $(<4 \mathrm{eV})$ neutron transport and temperature corrections for body temperature. The post processing code that converts the fluxes output from MCNP to absorbed dose and dose equivalent was upgraded with the addition of red bone marrow kerma factors, the new weighting factors proposed by the International Commission on Radiological Protection (ICRP), and a statistical error analysis. The new set of organ dose and effective dose equivalent data and has been compared to the ICRP Publication 51 data and independent calculations by R. A. Hollnagel at the Physikalisch-Technische Bundesanstalt (PTB) in Germany with good agreement at most energies.

Benchmark measurements were performed using a male RANDO phantom loaded with thermoluminescent dosimeters (TLDs) and track etch dosimeters (TEDs). The phantom was exposed to bare and $\mathrm{D}_{2} \mathrm{O}$-moderated ${ }^{252} \mathrm{Cf}$ at the PNL LowScatter Facility. The TLDs consisted of bare and cadmium-wrapped TLD-600s and TLD-700s for a determination of the gamma component and the low-energy neutron component. Sets of these TLDs were also irradiated in the thermal beam at the National Institute of Standards and Technology (NIST) to provide calibration data for use in interpreting the dosimeter responses. The female RANDO phantom purchased under FY 1989 capital equipment was received during March 1990. This was the last phantom manufactured with a real human skeleton. Having this new phantom allows us to make experimental comparisons of dosimeter responses and organ dose equivalents between male and female phantoms.

Work has begun on a computer code that will calculate effective dose equivalent due to incident fields of neutrons and photons from dosimeter responses. The utility code will read a data library containing the organ dose equivalents calculated by MCNP and estimate the effective dose equivalent for a known spectrum of neutrons such as from a multisphere or ${ }^{3} \mathrm{He}$ measurement. Also, something must be known about the source 
geometry or the most conservative geometry is used. The utility code also gives the user the option to choose from the ICRP 1977 sexaveraged weighting factors, the sex-specific weighting factors, or the new proposed ICRP 1990 weighting factors.

\section{Optically Stimulated Luminescence}

\section{S. D. Miller and P. A. Eschbach}

During FY 1990 a number of technical accomplishments were made that were critical steps towards producing a Cooled Optically Stimulated Luminescence (COSL) plastic matrix fast neutron dosimeter. Plastic matrix materials have a melting point far below the temperature required for thermally annealing COSL powder. Research focused on the development of an annealing procedure that does not require heating above room temperature. The procedure involves optical erasure using an intense ultraviolet laser and can be accomplished in less than one minute. The results of the research were published in Radiation Protection Dosimetry (Miller et al. 1989). The stability of a radiation dosimeter as a function of time is an important parameter. A fade study was completed during FY 1990 that demonstrated no fading within the statistical limits of the experiment. After the accomplishment of these two major research objectives, suppliers for the manufacturing of prototype COSL plastic matrix fast neutron dosimeters were solicited. After a difficult search, a number of suppliers were identified to manufacture prototype plastic matrix dosimeters for testing during FY 1991.

A DOE patent was issued at the end of FY 1990 on the COSL technology developed under the Applied Research Program. Additional studies into infra-red emission in alkali-halides were accomplished that demonstrated some interesting COSL properties that were previously unknown. The existence of radiation damage centers in alkalihalides that absorb in the visible and emit in the infra-red were documented in the study. The information was turned into the PNL's Intellectual Property Services Department in an effort to secure another DOE patent. During the course of the COSL studies, a new class of scintillators were discovered. The scintillators are extremely efficient, do not absorb their own scintillations, and emit light in convenient wavelength bands. The new class of scintillators could form the basis of a solid-state Tissue Equivalent Proportional Counter or provide a new technology to produce rugged portable survey instruments for DOE facilities.

\section{Superheated Drop Detector}

\section{R. Sisk and R. E. Apfel (Apfel Enterprises)}

A final report detailing progress on the superheated drop detector through FY 1989 was published by the subcontractor, Apfel Enterprises. Efforts by the subcontractor on a third generation prototype were initiated. The work culminated in the development of a microprocessor-based unit designed to overcome linearity and temperature problems identified in previous versions. The subcontractor composed a video presentation describing the capabilities of the latest prototype. The video presentation was reviewed by PNL.

\section{Reference}

Miller, S. D., K. A. Stahl, G.W.R. Endres, and J. C. McDonald. 1989. "Optical Annealing of $\mathrm{CaF}_{2}: \mathrm{Mn}$ for Cooled Optically Stimulated Luminescence." Radiat. Prot. Dosim. 29(3):195-198. 


\title{
Occupational Protection Program Development and Assessment
}

\author{
Project Managers: L. H. Munson and J. M. Selby
}

The purpose of this effort is to aid in developing a program for assessing the effectiveness of occupational protection at U.S. Department of Energy (DOE) facilities, and for providing technical resources in health physics, industrial hygiene, occupational health, and accident assessment aspects of radiological and nonradiological emergency preparedness to DOE's Office of Health (EH-41). Included is the assessment of needed improvements in occupational health programs and activities and the analysis of the impact of standards, regulations, and engineering or administrative actions on such programs. Assistance includes review of field implementation difficulties, resolution of ambiguities in the regulations, development of technical background information, and development of guidance and standards to assist in DOE Order implementation. Technical assistance is provided in the form of specific priority tasks or through special studies identified and scoped by DOE in connection with their oversight and compliance functions. The effort also provides the health physics, industrial hygiene, occupational health, and accident assessment expertise necessary to respond quickly and appropriately to the questions and issues that arise during the operation of DOE's nuclear energy research, development, demonstration, and production facilities.

\section{Environmental Protection Agency (EPA) Protective Action Guide (PAG) Tasks}

\author{
L. H. Munson, E. E. Hickey, T. A. Ikenberny, \\ M. A. Kellogg, J. R. Johnson, G. A. Stoetzel, \\ B. E. Vesper, S. E. Merwin, M. P. Moeller, \\ R. L. Hill, G. F. Martin, D. W. Blondin, \\ R. W. Schultz, R. F. Darwin, and C. S. Glantz
}

The purpose of these tasks was to develop general and specific information necessary to assist DOE in guiding EPA in its revision of the EPA PAG Manual and its application to DOE sites and facilities. Six papers were prepared, provided to DOE-HQ personnel, and distributed to members of the Subcommittee on Dose Assessment. The white papers were:

1. "Definition of Dose" - This paper is a review of the definition of radiation dose and potential health effects. Issues discussed included energy deposition, dose determination, types of exposure, stochastic and nonstochastic effects, genetic and somatic effects, committed dose equivalent and effective dose equivalent. Dose units were evaluated to determine those best suited for PAGs. The evaluation included discussion of differences in calculating internal exposures as committed effective dose equivalent and external exposures as effective dose equivalent using isotopic mixtures consistent with postulated DOE source terms.

2. "Estimating the Error in Dose Calculational Methods" - This paper identified and documented the parameters affecting dose calculations to assess the error associated with input values. The errors were analyzed in terms of both uncertainty and conservatism through promulgation of errors analysis. The errors evaluated included those associated with algorithms used for modeling plume movement, exposure of individuals, and dose determination.

3. "Comparison of Proposed and Existing Guidance" - This paper compiled and compared the existing EPA PAG guidance and the proposed EPA PAG revisions. The radiological source terms associated with commercial nuclear power facilities and DOE facilities were contrasted and analyzed to highlight difference in PAG requirements. The evaluation included a review of the differences in radionuclides and radionuclide mixtures, in release pathways, emission rates and dispersion characteristics.

4. "Optimization and Emergency Preparedness Planning" - This paper examined the applicability and use of optimization-through-valueimpact analysis in emergency planning and 
response. Case studies were prepared demonstrating the need for flexibility in PAGs, and a historical review of PAGs indicating how flexibility was previously provided was included.

5. "Determination of Risk from Radiation Doses" The impact of the guidance proposed by EPA was assessed through a determination and review of the methodology for comparing risk from radiation dose with risk from other sources. The paper included a discussion of the factors affecting the assignment of risk not addressed in the EPA calculations, such as assignment of risk for delivered dose rate. It also discussed methods for comparing radiation dose and health effects to risk from other sources and the cost equivalency associated with dose from both collective effective dose equivalent and collective committed effective dose equivalent.

6. "Estimating Costs Associated with PAGs" - This paper determined the cost of implementing PAGs, such as sheltering, evacuation, and other mitigative measures, for a representative sample of DOE sites. It also evaluated the appropriateness of costs assigned by EPA in their assessment of PAGs at DOE sites.

7. "Effectiveness of Sheltering in Buildings and Vehicles for Plutonium" - This paper provided a review of available data relevant to sheltering against inhalation of particles and gases from accidental releases. Equations for the reduction of dose and for interior concentrations were prepared. Representative dose reduction factors were calculated for residences and office buildings.

A subcontract provided on-site assistance to DOE$H Q$ staff in support of DOE response to EPA PAG proposed revisions and the development of Emergency Response Protection Guides for nonradiological hazardous materials.

A summary report of the papers prepared and recommendations for DOE implementation of the EPA PAG guidance was initiated and a draft provided to DOE-HQ for review and comment.

\section{Workshops on Classification of Events}

\author{
J. D. Jamison and G. F. Martin
}

The purpose of this task is to provide support to field elements and individual contractors as authorized by DOE-EH in developing and implementing event classification procedures. It includes providing regional workshops on classification of hazardous material emergencies at DOE facilities. Assistance was provided to Westinghouse Hanford Company EP staff in preparing and implementing a new Emergency Classification Procedure for the Fast Flux Test Facility and to DOE-Idaho (DOE-ID) and DOE-ID contractors for Emergency Action Level (EAL) development for several of their facilities and operations. Regional workshops were held at Oak Ridge, Tennessee, and Denver, Colorado.

\section{Draft of DOE 5500.3A Implementation Guidance}

\section{J. D. Jamison and E. E. Hickey}

The purpose of this work is to develop detailed guidance for use by DOE field elements and contractors in implementing DOE Order 5500.3A. Two prototype sections of the proposed guidance document were prepared and submitted to DOE$H Q$ for review and concurrence as to scope and depth of the guidance.

\section{Assessment Program Development}

L. H. Munson, G. R. Cicotte, E. E. Hickey,

T. J. Froelich, P. C. Olsen, and G. A. Stoetzel

The purpose of this work is to develop an assessment program for DOE staff to use in evaluating the implementation of occupational health programs and the adequacy of oversight by DOE area, field, program, and operations offices. Activities include preparation of analytic tree charts, inspection and assessment modules, and training programs for DOE assessment personnel. The efforts encompass the occupational health areas of radiation protection, industrial hygiene, and emergency preparedness, including consequence assessment for both radiological and nonradiological hazards. 
Health physics modules, 22 detailed inspection modules, and the same number of assessment modules, have been prepared and transmitted to DOE-HQ for review and comment. Thirteen industrial hygiene assessment modules were also prepared for $H Q$ review. Development of analytic trees to ensure consistent and coordinated assessment of health programs and DOE field element oversight was initiated. 
. 
Safety Appraisals and Quality

Assurance 
- 


\section{Deputy Assistant Secretary for Safety Appraisals and Quality Assurance}

The U.S. Department of Energy (DOE) Assistant Secretary for Safety, Health, and Environment has assigned to the Deputy Assistant Secretary for Safety Appraisals and Quality Assurance the responsibility for developing and promulgating nuclear safety standards and guiding and conducting appraisals and reviews of DOE facilities and operations. This office is also responsible for the conduct of DOE-wide independent overview, support, and counsel in all safety-related disciplines. The objectives of these programs are to aid DOE in ensuring that the activities of DOE and its contractors are in full compliance with applicable nuclear safety and emergency preparedness standards and regulations, and to provide technical support to the DOE Assistant Secretary for Environment, Safety, and Health. To accomplish this, Pacific Northwest Laboratory (PNL) is assisting DOE in achieving its mission through the following projects:

- Radiation Protection Support to the Department of Energy for Technical Safety Appraisals

- Safety Analysis Report Reviews

- Technical Support of Radiation Protection Requirements. 


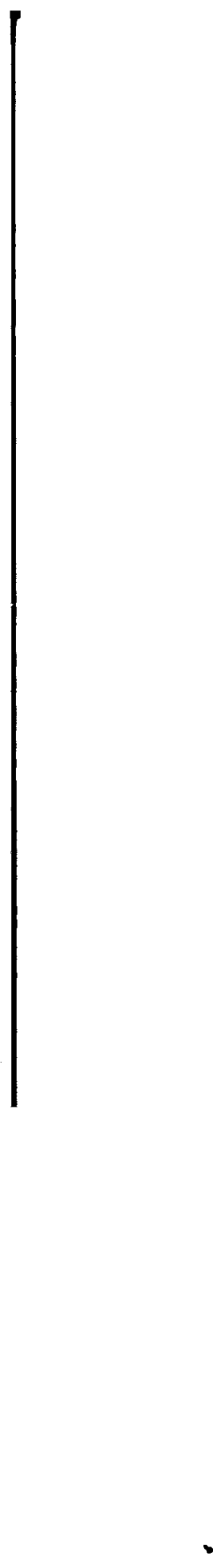

-

$$
\therefore
$$




\title{
Radiation Protection Support to the Department of Energy for Technical Safety Appraisals
}

\author{
Program Manager: L. G. Faust
}

The purpose of the Radiation Protection Support for Technical Safety Appraisals project is to provide technical support in radiation protection, personnel protection, emergency readiness and various other disciplines to the U.S. Department of Energy (DOE) Office of Safety, and Quality Assurance organization for its contractor safety oversight program. The contractor safety oversight program supports the DOE Environment, Safety, and Health (EH) Division's responsibility for the health and safety standards related to the operation of DOE facilities. Key elements of this program are the Technical Safety Appraisals (TSAs), Tiger Teams (TTs), and other functional appraisals of DOE contractor-operated sites and facilities.

The Radiation Protection Support project provides professional staff with varied specialized technical expertise and experience, whose areas of expertise are matched with the case-specific needs of the particular facility to be reviewed. The reviews include design, operational, organizational, and managerial aspects related to the operation of reactors; critical facilities, uranium, plutonium, and tritium processing facilities; as well as other supporting facilities.

Technical Safety Appraisals address radiation protection objectives in 13 different areas, emergency preparedness and security/safety interfaces in 7 areas, and personnel protection in 7 areas. Tiger Teams cover the same areas but usually not as in-depth, whereas functional appraisals are directed to a single element, e.g., fire protection or radiation protection.

Assigned staff accomplish their assignment by reviewing records and procedures, directly observing facility operations, and interviewing facility personnel. All projects are integrated by and conducted under the direction of a DOE team leader who is responsible for the specific appraisal. However, other activities, such as follow-up appraisals, quick response assistance, in-depth technical investigations, and independent analysis of specific topics, are included as appropriate, on a case-by-case basis and as agreed upon by the team leader or the DOE and Pacific Northwest Laboratory (PNL) program managers.

In order to provide rapid response, PNL has established subcontracts with other DOE laboratories, private consultants, and companies currently totalling about 25 different organizations. The expertise represented by the organizations under these subcontracts covers all aspects of a safety program as well as various other disciplines.

Subcontracting efforts are accomplished by the Subcontracts Section of PNL's Contract Services Department. PNL's procurement and subcontracts functions successfully passed the DOE-conducted Contractor Procurement System Review in December 1984. As a result, PNL procurement and contracting authority levels have been substantially increased and the procurement lead times have been dramatically reduced.

During FY 1990, PNL participated in two follow-up appraisals, five TSAs, seven TTs, and four other reviews of action plans, performance objectives, and related activities. 
. 


\section{Safety Analysis Report (SAR) Reviews}

\section{Project Manager: L. G. Faust}

The purpose of this project is to provide technical support in reviewing Safety Appraisal Reports (SARs), operational readiness reviews (ORRs) and review of other supporting documentation for the U.S. Department of Energy (DOE) Office of Safety and QA (OSQA) organization for its contractor oversight program. The contractor oversight program supports DOE's responsibility for the maintenance of health and safety standards related to the operation of DOE facilities.

The SAR project provides professional staff with varied, specialized technical expertise and experience depending on the facility under review. The reviews include all safety-related aspects of the facility, including operational readiness, documentation of occupational health and safety policies, programs, and procedures, and the facilities' ability to adhere to the stated policies.

During FY 1990, PNL participated in the SAR review for Westinghouse's Replacement Tritium Facility (RTF) at the Savannah River Site. This effort included review of several chapters of the SAR including decontamination and decommissioning, emergency preparedness, safety protection systems, facility safety programs, and waste confinement and management. The project also provided partial funding for the preparation of guides for the completion of an SAR and the review of an SAR.

Activities for FY 1991 will include completion of the RTF SAR review as well as technical support to DOE for review of other facilities as requested in support of their contractor oversight program. 



\title{
Technical Support of Radiation Protection Requirements (5480.11)
}

\author{
Project Managers: J. M. Selby and K. L. Swinth
}

The purpose of this program is to provide health physics support to the U.S. Department of Energy's (DOE) Office of Health in the implementation of DOE Order 5480.11, "Radiation Protection for Occupational Workers," and other supporting orders (e.g., 5484.1 and 5480.4). Assistance includes review of field implementation difficulties, resolution of ambiguities in the orders, development of technical background information, and development of standards to assist in implementing the order(s). Technical assistance is provided by Pacific Northwest Laboratory (PNL) in the form of specific priority tasks or through special studies identified and scoped by DOE in connection with their overview and compliance functions.

\section{Guidance for Implementation of Revised DOE Orders for Internal Dosimetry}

\section{J. M. Selby and D. R. Fisher}

The purpose of this task is to prepare and evaluate the performance standard on internal dosimetry, completing the work begun by the DOE Expert Group on Internal Dosimetry. The revised DOE Orders for internal dosimetry require a complete revision of internal dose assessment methods, the summing of internal and external doses, more extensive recording and reporting, and adoption of new dosimetric quantities. Version 8.0 of the draft Performance Standard for Internal Dosimetry programs was completed by the Expert Group, revised following a committee meeting in November, and submitted to DOE-HQ for review and comment. The Expert Group remains active, although it has not been given further instructions by DOE-HQ to complete the draft standard. Significant work remains to put the draft Standard into final form.

\section{Standard for Implementation of Revised DOE Orders for External Dosimetry}

\section{G. Faust and J. E. Tanner}

A departure draft standard was written to assist in implementing DOE Order 5480.11 as it pertains to external dosimetry. This standard will provide guidance in establishing and maintaining effective external dosimetry programs at DOE facilities. The format of the departure draft was styled after the internal dosimetry performance standard and contains DOE requirements, NCRP and ICRP recommendations, and where possible, guidance to good practices. The revised draft will be ready for external review by other DOE sites the first part of FY 1991.

\section{Air Sampling and Monitoring Guidance}

\section{B. E. Vesper}

Pertinent literature was reviewed and performance standards were coordinated with NRC progress on a similar document. Selected chapters, including the Introduction, Need for Air Sampling and Monitoring, Grab Sampling, General Air Sampling, Breathing Zone Sampling, and Real Time Monitoring were completed and submitted to the sponsor. In FY 1991, efforts will continue on completion of the remaining chapters and ensuring a comprehensive document that can be used in the development and maintenance of a facility air monitoring program. This document will have the basic requirements, guidance for procedures, and the technical information necessary to establish a state-of-the-art program.

\section{Guidance for Contamination Control Policy at DOE Sites}

\section{H. Munson and G. R. Cicotte}

DOE-EH requested the preparation of a standard/guidance document on contamination control for DOE facilities. The format and emphasis of the document was revised to provide detailed standards guidance for contamination control. The document will be a supporting document for a generic radiation protection guide being developed. 
The October 1989 Oak Ridge Operations Radioactive Contamination Control Policy was reviewed to verify its compliance to DOE 5480.11 and good practices.

\section{Guidance for Contamination Measurement Levels}

\section{K. L. Swinth}

The purpose of this task is to review the impact of various contamination levels on potential worker/ public exposures and compare these levels with Attachment 2 of 5480.11 and known instrument capabilities. The contamination measurement capability of portable instruments was reviewed. The review indicated that large-area $\left(>1 \mathrm{~m}^{2}\right)$ contamination will be found at Attachment 2 levels, but small areas (point source) will not be detected unless unusually slow survey speeds are employed. A comparison of contamination levels provided in Attachment 2 of Order 5480.11 against acceptable levels for residual contamination in an NRC document (NUREG/CR-5512) was completed and submitted to DOE-EH.

An ISO working group meeting on Evaluation of Contamination was attended and comments were provided on a standard setting forth means of evaluating contamination.

\subsection{Upgrades}

\section{J. M. Selby and K. L. Swinth}

A significant effort was expended to list the issues associated with implementation of 5480.11. As part of this effort, 78 comments received by DOE were categorized by the DOE Order paragraph number. With the assistance of DOE-EH personnel, these comments were condensed into significant comments. The DOE response to all significant comments was identified and stated on a summary table. The DOE response was obtained from information provided by DOE-EH staff personnel.
A rationale/basis document for 5480.11 was sent to DOE-HQ in letter form. A technical review of field office comments on 5480.11 was conducted and comments were sent to headquarters.

\subsection{Upgrades}

\section{J. M. Selby and K. L. Swinth}

The 5484.1 revisions focused on the need to develop a monitoring and record keeping methodology that would ensure that radiation workers doses would be adequately and effectively identified, recorded, and reported. This included identification of record keeping requirements necessary to clearly characterize the requirements for all individuals entering a DOE complete facility, whether they require radiation monitoring badging or not. Furthermore, the methodology as expressed in DOE Order 5484.1 is to ensure that no duplicate records would be kept on individuals which could result in an inaccurate assessment of radiation exposure resulting from DOE facilities.

\section{Special Analyses per DOE Request}

\section{J. M. Selby and K. L. Swinth}

Revised drafts of both 5480.11 and 5484.1 were sent to DOE-EH, DOE sites, and contractors for review and evaluation. Support was supplied in the review of the comments and an assessment as to whether the revised requirements could be implemented. PNL staff accompanied DOE staff on their visit to several DOE sites during December 1989.

Information on an earlier review of 5480.4 was sent to DOE-HQ for review and comment. A proposed revision was sent to DOE-EH for review and comment. 


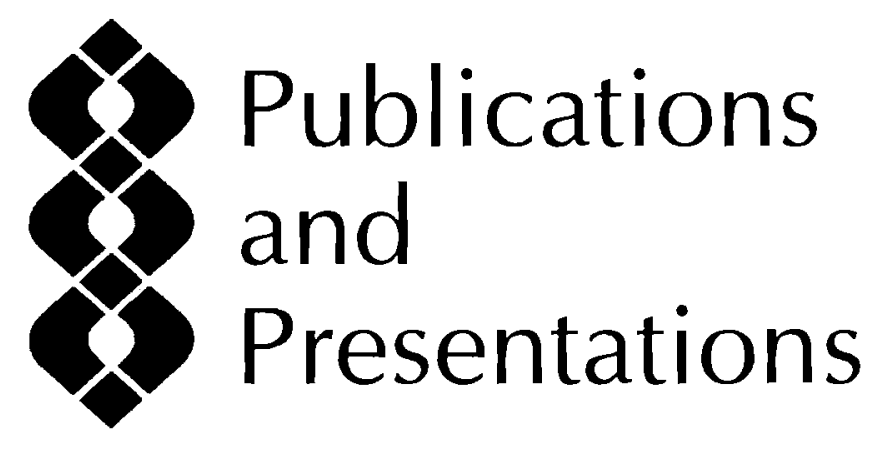


. 


\section{Publications}

Beck, D. M. 1990. Guidance on Public Participation for U.S. Department of Energy Environmental Restoration Activities. ICF Kaiser Engineers, Richland, Washington.

Doctor, P. G., T. B. Miley, and C. E. Cowan. 1990. Multimedia Environmental Pollutant Assessment System (MEPAS) Sensitivity Analysis of Computer Codes. PNL-7296, Pacific Northwest Laboratory, Richland, Washington.

Droppo, J. G., Jr., J. W. Buck, D. L. Strenge, and M. R. Siegel. 1990. Analysis of Health Impact Inputs to the U.S. Department of Energy's Risk Information System. PNL-7432, Pacific Northwest Laboratory, Richland, Washington.

Droppo, J. G., Jr., G. Whelan, J. W. Buck, D. L. Strenge, B. L. Hoopes, and M. B. Walter. 1989. Supplemental Mathematical Formulations: The Multimedia Environmental Pollutant Assessment System (MEPAS). PNL-7201, Pacific Northwest Laboratory, Richland, Washington.

Droppo, J. G., Jr., D. L. Strenge, J. W. Buck, B. L. Hoopes, R. D. Brockhaus, M. B. Walter, and G. Whelan. 1989. Multimedia Environmental Pollutant Assessment System (MEPAS) Application Guidance Volume 1 - User's Guide. PNL-7216, Pacific Northwest Laboratory, Richland, Washington.

Droppo, J. G., Jr., and B. L. Hoopes. 1990. "Remedial Action Priority and Multimedia Environmental Pollutant Assessment Systems." In Expert Systems for Environmental Applications, J. M. Hushon, Editor, American Chemical Society.

Droppo, J. G., Jr., D. L. Strenge, J. W. Buck, B. L. Hoopes, and G. Whelan. 1989. Multimedia Environmental Pollutant Assessment System (MEPAS) Application Guidance Volume 2 Guidelines for Evaluating MEPAS Input Parameters. PNL-7216, Pacific Northwest Laboratory, Richland, Washington.
Fisher, D. R., M. J. Swint, and R. L. Kathren. 1990. Evaluation of Health Effects in Sequoyah Fuels Corporation Workers from Accidental Exposure to Uranium Hexafluoride. NUREG/CR-5566, Pacific Northwest Laboratory, Richland, Washington.

Harty, R., W. D. Reece, C. D. Hooker, and J. C. McDonald. 1990. Performance Testing of Extremity Dosimeters Against a Draft Standard. PNL-7277, Pacific Northwest Laboratory, Richland, Washington.

Hertel, N. E., and J. C. McDonald. 1990. "Calculations of Anisotropy Factors and Dose Equivalents for Unmoderated Cf-252 Sources." Radiat. Prot. Dosim. 32:77-82.

Hertel, N. E., and J. C. McDonald. 1990. "Calculated Dosimetric Quantities for $\mathrm{D}_{2} \mathrm{O}$ Moderated CF252 Snu Irrae "Sithmittod to Madiation Drntartion Dosimetry.

Hertel, N. E., and J. C. McDonald. 1990. "Methods for the Calibration of Photon Personnel Dosimeters in Terms of the Ambient Dose Equivalent." Radiat. Prot. Dosim. 32:149-156.

Hickey, E. E. 1990. Optimization of Emergency Preparedness Planning. PNL-7380, Pacific Northwest Laboratory, Richland, Washington.

Hill, R. L., and J. R. Johnson. 1990. Dosimetric Quantities and Their Relationship to Risks to Individuals. PNL-7461, Pacific Northwest Laboratory, Richland, Washington.

Kellogg, M. A., D. W. Blondin, and R. W. Schultz. 1990. Estimation of Protective Action Costs at Six DOE Sites. PNL-7398, Pacific Northwest Laboratory, Richland, Washington.

Kruchten, D. A., and A. L. Anderson. 1990. "Improved Ultrasonic Measurement Techniques Applied to Assay of Pu and Other Transuranics in Lung." Health Phys. 59:117-123. 
Merwin, S. E., and R. F. Darwin. 1990. Determination of Risk from Radiation Doses. PNL-7415, Pacific Northwest Laboratory, Richland, Washington.

Merwin, S. E., and K. L. Swinth. 1989. "Performance of an Exoelectron Dosimetry Badge for Personnel Beta Dosimetry." Radiat. Prot. Dosim. 28(3):219-222.

Miller, S. D., and G.W.R. Endres. "Laser-Induced Optically Stimulated M-Center Luminescence in LIF." In Proc. 9th Int. Conf. on Solid State Dosimetry (to be published).

Miller, S. D., K. A. Stahl, G.W.R. Endres, and J. C. McDonald. 1989. "Optical Annealing of $\mathrm{CaF}_{2}: \mathrm{Mn}$ for Cooled Optically Stimulated Luminescence." Radiat. Prot. Dosim. 29(3):195-198.

Murphy, M. K. 1990. "Physical Characterization of a Cs-137 Field Used for Proficiency-Test Irradiations." Publication in Health Physics (in process).

Murphy, M. K., and J. C. McDonald. 1990. DOE RadiologicalCalibrations Intercomparison Program Results from Fiscal Year 1989. (in printing)

Stoetzel, G. A. 1990. Comparison of EPA's Proposed Protective Action Guides with Existing EPA and International Guidance. PNL-7371, Pacific Northwest Laboratory, Richland, Washington.

Strenge, D. L., R. A. Peloquin, M. J. Sula, and J. R. Johnson. 1990. Code for Internal Dosimetry (CINDY). Part 1: Conceptual Representation. PNL-7493, Pt.1, Pacific Northwest Laboratory, Richland, Washington.
Strenge, D. L., R. A. Peloquin, M. J. Sula, and J. R. Johnson. 1990. Code for Internal Dosimetry (CINDY). Part 2: User's Guide. PNL-7493, Pt.2, Pacific Northwest Laboratory, Richland, Washington.

Swinth, K. L, and D. R. Sisk. 1990. "Survey Instrument Response to Beta Radiations." IEEE Transactions on Nuclear Science, Vol. 27, No. 2, April 1990.

U.S. Department of Energy (DOE). June 1990. Closure of Hazardous and Mixed Radioactive Waste Management Units at DOE Facilities. Washington, D.C.

U.S. Department of Energy (DOE). September 1989. DOE Land Disposal Restrictions Strategy Report Radioactive Mixed Wastes. DOE/EH-231, Washington, D.C.

Vesper, B. E., and C. S. Glantz. 1990. Estimating the Unocrtainty in Dose Calculational Methods for Accidental Atmospheric Releases. PNL-7444, Pacific Northwest Laboratory, Richland, Washington.

Whelan, G., J. G. Droppo, Jr., D. L. Strenge, M. B. Walter, and J. W. Buck. 1989. A Demonstration of the Applicability of Implementing the Enhanced Remedial Action Priority System (RAPS) for Environmental Releases. PNL-7102, Pacific Northwest Laboratory, Richland, Washington. 


\section{Presentations}

Bailey, M. R., A. Birchall, R. G. Cuddihy, A. C. James, and M. Roy. 1990. "Respiratory Tract Clearance Model for Dosimetry and Bioassay of Inhaled Radionuclides." Presented at the 3rd International Workshop on Respiratory Tract Dosimetry, July 1-3, 1990, Albuquerque, New Mexico.

Birchall, A., M. R. Bailey, and A. C. James. 1990. "LUDEP: A Lung Dose Evaluation Program." Presented at the 3rd International Workshop on Respiratory Tract Dosimetry, July 1-3, 1990, Albuquerque, New Mexico.

Droppo, J. G. 1989. "Use of Environmental Monitoring Data in Evaluation of Modeling Results." PNL-SA-16867A, presented at the Twenty-Eighth Hanford Life Sciences Symposium on Health and the Environment, October 1989, Richland, Washington.

Fisher, D. R., M. J. Swint, and R. L. Kathren. 1990. "Dosimetry and Health Effects of Acute Exposure to UF ." 35th Annual Meeting of the Health Physics Society, Anaheim, California, June 24-28, 1990; Health Physics 50 (Supplement 1):S48.

Harty, R., J. C. McDonald, F. M. Cummings, C. D. Hooker, W. D. Reece, and R. J. Traub. 1990. "A Department of Energy Draft Standard for Performance Testing of Extremity Dosimetry." Presented at the 35th Annual Meeting of the Health Physics Society, June 24-28, 1990, Anaheim, California.

Harty, R., W. D. Reece, C. D. Hooker, and J. C. McDonald. 1990. "Performance Testing of Extremity Dosimeters." Presented at the Ninth Panasonic TLD International Symposium, June 18-22, 1990, Keystone, Colorado.

Hickey, E. E., M. P. Moeller, and D. M. Rohrer. 1990. "Optimization of Emergency Preparedness Planning." Presented at the 35th Annual Meeting of the Health Physics Society, June 24-28, 1990, Anaheim, California.
James, A. C., P. Gehr, R. Masse, R. G. Cuddihy, F. T. Cross, J. S. Durham, and J. K. Briant. 1990. 'Dosimetry Model for Bronchial and Extrathoracic Tissues of the Respiratory Tract." PNL-SA-18334A, presented at the 3rd International Workshop on Respiratory Tract Dosimetry, July 1-3, 1990, Albuquerque, New Mexico.

James, A. C., W. Stahlhofen, G. Rudolf, M. J. Egan, W. Nixon, and J. K. Briant. 1990. "The Respiratory Tract Deposition Model Proposed by the ICRP Task Group." PNL-SA-18335A, presented at the 3rd International Workshop on Respiratory Tract Dosimetry, July 1-3, 1990, Albuquerque, New Mexico.

Johnson, J. R., A. C. James, and A. Birchall. 1990. "Application of the Proposed New Lung Model to Bioassay." PNL-SA-18324A, presented at the 3rd International Workshop on Respiratory Tract Dosimetry, July 1-3, 1990, Albuquerque, New Mexico.

Johnson, J. R., R. A. Peloquin, M. J. Sula, D. R. Fisher, and D. L. Strenge. 1990. "CINDY-Code for Internal Dosimetry." 35th Annual Meeting of the Health Physics Society, Anaheim, California, June 24-28, 1990; Health Physics 50 (Supplement 1): S50.

Johnson, J. R., R. A. Peloquin, M. J. Sula, and D. R. Fisher. 1989. "CINDY--Code for Internal Dosimetry." In Computer Applications in Health Physics: 1989 Update. Presented at the Western Regional Symposium of the Health Physics Society, March 16-17, 1989, Richland, Washington.

Large, K. K., C. D. Hooker, J. C. McDonald, and R. J. Traub. 1990. "Photon Backscatter Measurements of the Polymethylmethacrylate Phantom Used in U. S. Personnel Dosimeter Accreditation Programs (NVLAP, DOELAP)." Presented at the 35th Annual Meeting of the Health Physics Society, June 26, 1990, Anaheim, California. 
Martin, J. B., D. M. Fleming, and K. L. Swinth. 1990. Practical Limitations on Alpha Contamination Monitoring." Presented at the 35th Annual Meeting of the Health Physics Society, June 26, 1990, Anaheim, California.

Merwin, S. E. 1990. "Exoelectron Dosimetry." Presented at the 9th Annual TLD International Symposium, June 18-22, 1990, Keystone, Colorado.

Merwin, S. E., K. P. Ferlic, W. H. Millet, D. R. Nelson, J. M. Selby, K. L. Swinth, and R. J. Traub. 1990. "Analysis of Radiation Doses Received by Workers at DOE Facilities." Presented at the 35th Annual Meeting of the Health Physics Society, June 24-28, 1990, Anaheim, California.

Merwin, S. E., M. P. Moeller, and D. M. Rohrer (U.S. DOE). 1990. "Evaluation of Risks for Establishing Protective Action Guides." Presented at the 35th Annual Meeting of the Health Physics Society, June 24-28, 1990, Anaheim, California.

Miller, S. D., and G.W.R. Endres. 1990. "Intra-red M-Center Luminescence for Radiation Dosimetry. " Health Physics Conference, June 1990, Anaheim, California.

Miller, S. D., and G.W.R. Endres. 1989. "LaserInduced Optically Stimulated M-Center Luminescences in LiF." 9th International Conference on Solid State Dosimetry, November 1989, Vienna, Austria.

Murphy, M. K. 1990. "Intercomparison of Cf-252 Absorbed Dose and Dose Equivalent Rates at NIST and PNL." Presented at the 35th Annual Meeting of the Health Physics Society, June 24-28, 1990, Anaheim, California.

Olsen, P. C., and T. P. Lynch. 1990. "An Intercomparison of Two Whole Body In Vivo Calibration Phantoms." Presented at the 35th Annual Meeting of the Health Physics Society, June 24-28, 1990, Anaheim, California.
Olsen, P. C. 1990. "Radiation Safety Training Requirements for the Department of Energy Work Force."

Selby, J. M., K. L. Swinth, and J. C. McDonald. 1990. "Overview of International Standards Development." Presented at the 35th Annual Meeting of the Health Physics Society, June 24-28, 1990, Anaheim, California.

Strenge, D. L., and J. W. Buck. 1989. "Chemical Exposure Evaluation in the Multimedia Environmental Pollutant Assessment System (MEPAS)." PNL-SA-16909A, presented at the Twenty-Eighth Hanford Life Sciences Symposium on Health and the Environment, October 1989, Richland, Washington.

Swinth, K. L., and D. R. Sisk. 1990. "Survey Instrument Response to Beta Radiations." Presented at the Institute of Electrical and Electronic Engineers Nuclear Science Symposium, January 16-19, 1990, San Francisco, California.

Swinth, K. L., J. D. McDonald, and J. M. Selby. 1990. 'The Accreditation Process and Performance Standards." Presented at the 35th Annual Meeting of the Health Physics Society, June 24-28, 1990, Anaheim, California.

Tanner, J. E., R. J. Traub, and R. I. Scherpelz. 1990. PNL-SA-17715, Poster Presentation at the 35th Annual Meeting of the Health Physics Society, June 24-28, 1990, Anaheim, California.

Traub, R. J., and K. L. Swinth. 1990. "Spectra of Scattered Photons from Irradiators Used for Dosimeter and Instrument Calibrations. "Presented at the 35th Annual Health Physics Society, June 24-28. 1990, Anaheim, California. 


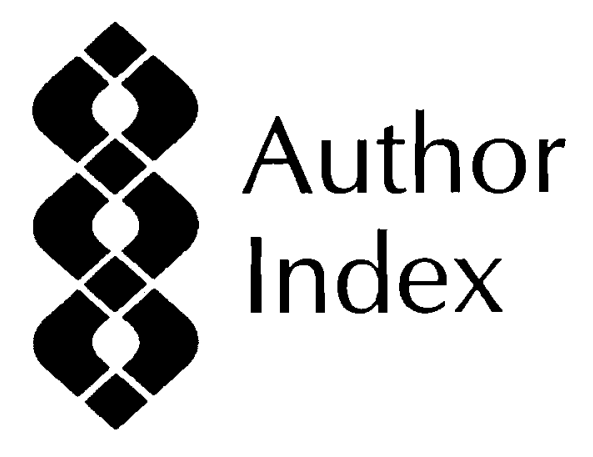


. 


\section{Author Index}

Aaberg, R.L., 4

Abrams, C.W., 10

Apfel, R.E. (Apfel

Enterprises, Inc.), 38

Baker, D.A., 4

Beck, D.M., 9

Bilyard, G.R., 4, 10

Blondin, D.W., 39

Brackenbush, L.W., 36

Buck, J.W., 5

Cicotte, G.R., 40, 49

Darwin, R.F., 39

Doctor, P.G., 13

Droppo, J.G., Jr., 5, 10

Durham J.S., 19, 21

Endres, G.W.R., 21

Eschbach, P.A., 38

Faust, L.G., 49

Fisher, D.R., 29, 33, 34, 49

Froelich, T.J., 40

Glantz, C.S., 39

Geffen, C.A., 13

Gianti, S.J. (CH2M Hill), 13

Grove, L.K., 3

Hankins, D.E., 36

Harty, R., 31

Hickey, E.E., 13, 39, 40
Higley, K.A., 3

Hill, R.L., 10, 34, 39

Homann, S., 36

Hoopes, B.L., 5

Humphreys, K.K., 13

Ikenberry, T.A., 3, 4, 39

Jamison, J.D., 40

Johnson, J.R., 29, 39

Joseph, J.A., 4

Keller, J.F., 9, 13

Kellogg, M.A., 39

Kennedy, W.E., Jr., 3, 4

Lesperance, A.M., 13

Longstreth, J.D., 10, 13

Martin, G.F., 39, 40

McDonald, J.C., 31,32

Medearis, K. (Booz Allen,

Hamilton, Inc.), 13

Merwin, S.E., 19, 39

Miller, S.D., 19, 38

Moeller, M.P., 39

Munson, L.H., 39, 40, 49

Murphy, M.K., 32

Napier, B.A., 4, 10

Neuder, S.M., 3

Olsen, P.C., 33, 40
Parkhurst, M.A., 36

Peloquin, R.A., 29

Scherpelz, R.I., 36

Schultz, R.W., 39

Selby, J.M., 23, 25, 49, 50

Siegel, M.R., 9, 13

Sisk, D.R., 20, 38

Smith, J.D., 9

Smith, M.H., 19

Soldat, J.K., 3, 4

Stenner, R.D., 4

Stewart, R.D., 37

Stoetzel, G.A., 39,40

Strenge, D.L., 5, 29

Sula, M.J., 29

Swahn, R. (ICF, Inc.), 13

Swinth, K.L., 20, 23, 25, 26, 28, 50

Tanner, J.E., 37, 49

Templeton, W.L. 3

Thorngate, J.L. (LLNL), 36

Traub, R.J., 37

Triplett, M.B., 9

Van Epp, T.D. (CH2M Hill), 13

Veitenheimer, S.J., 13

Vesper, B.E., 39, 49

Woodruff, M.G., 13 
• 


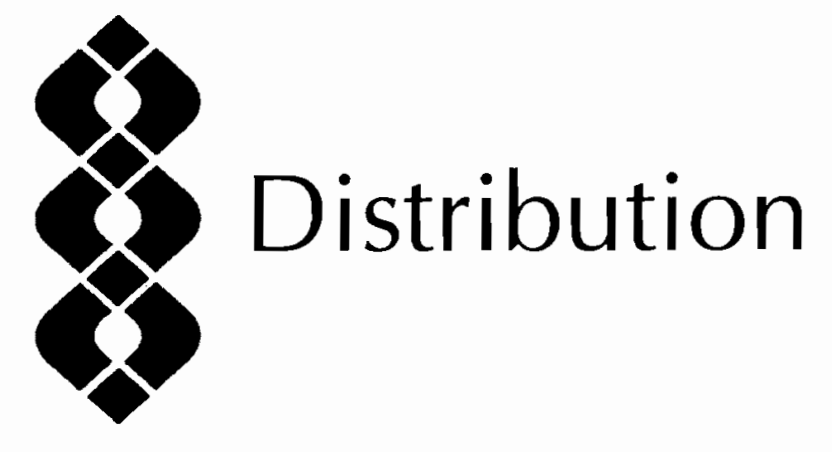


. 
PNL-7600, Pt. 5

UC-407

\section{Distribution}

\section{OFFSITE}

R. J. Aiken

Department of Energy

1000 Independence Ave. SW

Washington, DC 20585

W. R. Albers

EH-12, GTN

Department of Energy

Washington, DC 20545

A. L. Anderson

Lawrence Livermore National

Laboratory, L-383

P. O. Box 5505

Livermore, CA 94550

D. Anderson

ENVIROTEST

1108 NE 200th Street

Seattle, WA 98155-1136

\section{P. L. Ziemer}

Assistant Secretary

Environment, Safety \& Health

Division

EH-1, FORS

Department of Energy

Washington, DC 20585

\section{J. A. Auxier}

IT Corporation

312 Directors Drive

Knoxville, TN 37701

F. Badgley

13749 NE 41st Street

Seattle, WA 98125

R. W. Barber

EH-131, GTN

Department of Energy

Washington, DC 20545
A. D. Barker

Battelle Columbus Laboratories

505 King Avenue

Columbus, $\mathrm{OH} 43201$

N. F. Barr

ER-72, GTN

Department of Energy

Washington, DC 20545

J. H. Barry

Idaho Operations Office

Department of Energy

785 DOE Place

Idaho Falls, ID 83402

J. W. Baum

Brookhaven National Laboratory

Bldg 703-M

Upton, Long Island, NY 11973

E. C. Baynard, III

EH-1, FORS

Department of Energy

Washington, D.C. 20585

R. T. Bell

Office of Health

EH-40

Department of Energy

Washington, DC 20545

R. P. Berube

Deputy Assistant Secretary

for Environment

EH-20 FORS

Department of Energy

Washington, DC 20585

W. R. Bibb

Energy Programs and Support Division

Department of Energy

P. O. Box 2001

Oak Ridge, TN 37831
A. E. Bicker

ReeCo

P. O. Box 98521

Las Vegas, NV 89193

E. Blackwood

Environment, Safety,

\& Health Division

Office of Safety Compliance

$\mathrm{EH}-34$

Department of Energy

Washington, DC 20545

C. M. Borgstrom

Acting Director, NEPA

EH-25, Room 3E080

Department of Energy

1000 Independence Ave. SW

Washington, DC 20585

L. C. Brazley, Jr.

NE-22, GTN

Department of Energy

Washington, DC 20545

D. N. Bridges

DOE - Savannah River

Operations Office

P. O. Box A

Aiken, SC 29801

A. Brodsky

2765 Ocean Pines

Berlin, MD 21811-9127

G. Burley

Office of Radiation Programs

ANR-458

Environmental Protection

Agency

Washington, DC 20460 
PNL-7600, Pt. 5

UC-407

W. D. Burnett

Sandia National Laboratories

Department 3210

P. O. Box 5800

Albuquerque, NM 87185

W. W. Burr, Chairman

Medical \& Health Sciences

Division

Oak Ridge Associated

Universities

P. O. Box 117

Oak Ridge, TN 37830

L. K. Bustad

College of Veterinary Medicine

Washington State University

Pullman, WA 99164-7010

G. W. Campbell

Lawrence Livermore National

Laboratory, L-382

P. O. Box 808

Livermore, CA 94550

D. Carathers

Pantex Plant

Mason \& Hanger--Silas Mason

Co., Inc.

P. O. Box 30020

Amarillo, TX 79109

R. J. Catlin, President

Robert J. Catlin Corporation

701 Welch Road, Suite 1119

Palo Alto, CA 94304

M. H. Chew

M. H. Chew \& Associates

1424 Concannon Blvd.

Livermore, CA 94550

P. Cho

ER-73, GTN

Department of Energy

Washington, DC 20545
M. J. Clausen

Mail Stop 9-A-2

Nuclear Regulatory

Commission

Washington, DC 20555

R. J. Cloutier

Oak Ridge Associated

Universities

P. O. Box 117

Oak Ridge, TN 37831-0117

N. Cohen

New York University Medical

Center

P. O. Box 817

Tuxedo, NY 10987

J. P. Corley, C.H.P.

2213 Torbett Street

Richland, WA 99352

L. V. Coulson

Fermi National Accelerator

Laboratory

P. O. Box 500

Batavia, IL 60510

Council on Environmental

Quality

722 Jackson Place, NW

Washington, DC 20503

T. R. Crites

Lawrence Livermore National

Laboratory, L-382

P. O. Box 808

Livermore, CA 94550

R. E. Cunningham

Nuclear Regulatory

Commission

Washington, DC 20555

J. T. Davis

San Francisco Operations

Office

Department of Energy

1333 Broadway
Oakland, CA 94612

Department of Energy

Health Protection Division

P. O. Box 5400

Albuquerque, NM 87115

Department of Energy

Attn: DP-222, GTN

Washington, DC 20545

G. DePlanque, Director

Department of Energy-EMEL

375 Hudson Street

New York, NY 10014

G. P. Dix

26619 Haney Avenue

Damascus, MD 20750

T. J. Dobry, Jr.

DP-221, GTN

Department of Energy

Washington, DC 20545

DOE/Office of Scientific \&

Technical

Information (12)

J. W. Doty

EG\&G Mound Applied

Technologies, Inc.

P. O. Box 3000

Miamisburg, $\mathrm{OH}$ 45343-0987

H. Drucker

Argonne National Laboratory

9700 South Cass Avenue

Argonne, IL 60439

A. P. Duhamel

ER-74, GTN

Department of Energy

Washington, DC 20545 
PNL-7600, Pt. 5

UC-407

\author{
K. F. Eckerman \\ Health Studies Section \\ Health and Safety Research \\ Division \\ Oak Ridge National Laboratory \\ P. O. Box 2008
}

Oak Ridge, TN 37831-6383

Health and Safety Research

Division

Oak Ridge National

Laboratory

P. O. Box 2008

Oak Ridge, TN 37831-6383

G. R. Eisele

Medical Division

Oak Ridge Associated

Universities

P. O. Box 117

Oak Ridge, TN 37830

E. H. Eisenhower

National Bureau of Standards \& Technology

Bldg. 245, Rm. C229

Gaithersburg, MD 20899

R. J. Engelmann

11701 Karen

Potomac, MD 20854

T. H. Essig

Mail Stop 11-D-23

Nuclear Regulatory

Commission

Washington, DC 20555

R. E. Faw

Kansas State University

Marihattan, KS 66506
B. H. Fimiani

Battelle, Pacific Northwest

Laboratories

Washington Operations

370 L'Enfant Promenade,

Suite 900

901 D Street, SW

Washington, DC 20024

J. E. Fitzgerald, Jr.

Office of Safety

$\mathrm{EH}-30$

Department of Energy

Washington, DC 20545

P. K. Fitzsimmons

Nevada Operations Office

Department of Energy

P. O. Box 14100

Las Vegas, NV 89114

W. O. Forster

ER/OHER/ERD

Department of Energy

Washington, DC 20545

T. F. Gesell

Idaho Operations Office

Department of Energy

785 DOE Place

Idaho Falls, ID 83402-4149

G. W. Gibbs

EH-151, GTN

Department of Energy

Germantown, MD 20545

R. D. Gilmore, President

Environmental Health Sciences, Inc.

Nine Lake Bellevue Building

Suite 104

Bellevue, WA 98005

M. Goldman

Department of Radiological

Sciences (VM)

University of California

Davis, CA 95616
R. Goldsmith

ER-73, GTN

Department of Energy

Washington, DC 20545

G. Goldstein

ER-74, GTN

Department of Energy

Washington, DC 20545

B. K. Grimes

Nuclear Regulatory

Commission

Washington, DC 20555

G. H. Groenewold

Energy and Mineral Research

Center

University of North Dakota

Box 8123, University Station

Grand Forks, ND 58202

R. M. Hall

Savannah River Laboratory

E. I. duPont de Nemours

\& Company

Aiken, SC 29801

R. E. Halliburton

Oak Ridge National Laboratory

Bldg. 2007, MS-6042

P. O. Box 2008

Oak Ridge, TN 37831-6042

D. H. Hamilton, Jr,

ER-72, GTN

Department of Energy

Washington, DC 20545

W. H. Hayes

Westinghouse Materials

Company of Ohio

P. O. Box 398704

Cincinnati, $\mathrm{OH} 45239$

J. W. Healy

51 Grand Canyon Drive

White Rock, NM 87544 
PNL-7600, Pt. 5

UC-407

D. B. Howard

DOE - Oak Ridge Operations Office

P. O. Box 2001

Oak Ridge, TN 38731-8731

A. P. Hull
Safety and Environmental
Protection Division
Brookhaven National
Laboratory
Building 535-A
Upton, Long Island, NY 11973

R. A. Hunter

NE-47, GTN

Department of Energy

Washington, DC 20545

R. O. Hunter, Jr.

ER-1, FORS

Department of Energy

1000 Independence Ave. SW

Washington, DC 20585

F. Hutchinson

Department of Molecular

Biophysics \& Biochemistry

Yale University

260 Whitney Avenue

P. O. Box 6666

New Haven, CT 06511

H. Ishikawa, General Manager

Nuclear Safety Research

Association

P. O. Box 1307

Falls Church, VA 22041

R. Jarrett

Office of Health

EH-40

Department of Energy

Washington, DC 20545
A. W. Johnson

Vice President for Academic

Affairs

San Diego State University

San Diego, CA 92182

C. R. Jones

Office of Health

$\mathrm{EH}-40$

Department of Energy

Washington, DC 20545

G. Y. Jordy, Director

ER-30, GTN

Department of Energy

Washington, DC 20545

G. J. Judge

EH-1, FORS

Department of Energy

Washington, DC 20585

R. F. Kendall

Bartlesville Energy Research Center

Department of Energy

P.O. Box 1398

Bartlesville, OK 74005

M. A. Kilpatrick, Acting Director

Office of Environmental Audit

EH-24, FORS

Department of Energy

Washington, DC 20585

K. D. Knight

EG-24

Department of Energy

Washington, DC 20545

Librarian

Brookhaven National

Laboratory

Research Library, Reference

Upton, Long Island, NY 11973
Librarian

Colorado State University

Documents Department--

The Libraries

Ft. Collins, CO 80523

Librarian

Electric Power Research

Institute

3412 Hillview Avenue

P. O. Box 10412

Palo Alto, CA 94303

Librarian

Frances Penrose Owen

Science \& Engineering Library

Washington State University

Pullman, WA 99164-3200

Librarian

Los Alamos National Laboratory

Report Library, MS P364

P. O. Box 1663

Los Alamos, NM 87545

Librarian

Washington State University

Pullman, WA 99164-6510

Library

Serials Department

(\#80-170187)

University of Chicago

1100 East 57th Street

Chicago, IL 60637

R. Loesch

Office of Health

$\mathrm{EH}-40$

Department of Energy

Washington, DC 20545

O. D. T. Lynch, Jr.

EH-33, GTN

Department of Energy

Washington, DC 20585 
J. N. Maddox

ER-73, GTN

Department of Energy

Washington, DC 20545

J. R. Maher

ER-65, GTN

Department of Energy

Washington, DC 20545

C. R. Mandelbaum

ER-32, GTN

Department of Energy

Washington, DC 20545

\section{S. Marks}

U.S. Marine Corps. Air Station ABCC/RERF

FPO

Seattle, WA 98764-5000

P. O. Matthews

Department of Energy

P. O. Box A

Aiken, SC 29802

R. C. McCall

Stanford Linear Accelerator

P. O. Box 4349

Stanford, CA 94305

H. M. McCammon

ER-75, GTN

Department of Energy

Washington, DC 20545

R. O. McClellan, President

Chemical Industry Institute of Toxicology

P. O. Box 12137

Research Triangle Park,

NC 27709

D. N. McNelis

ReeCo

P. O. Box 98521

Las Vegas, NV 89193
W. T. Mee

$\mathrm{T}-12$

P. O. Box $Y$

Oak Ridge, TN 37830

C. B. Meinhold

Radiological Sciences Division

Bldg. 703M

Brookhaven National

Laboratory

Upton, Long Island, NY 11973

M. L. Mendelsohn

Biomedical and Environmental Research Program

Lawrence Livermore National

Laboratory, L-452

University of California

P. O. Box 5507

Livermore, CA 94550

C. Miller

P.O. Box 180

Watermill, NY 11976

W. A. Mills

Committee on Interagency

Radiation Research \& Policy Coordination (CIRRPC)

Oak Ridge Associated

Universities

1019 19th Street, NW

Suite 700

Washington, DC 20036

H. J. Moe

Argonne National Laboratory

9700 South Cass Avenue

Argonne, IL 60439

D. W. Moeller

Harvard School of Public Health

677 Huntington Avenue

Boston, MA 02115
D. R. Monti

ER-14, GTN

Department of Energy

Washington, DC 20545

D. O. Moses

EH-23, GTN

Department of Energy

Washington, DC 20545

W. D. Moss

Group HSE9, MS-484

Los Alamos National

Laboratory

P. O. Box 1663

Los Alamos, NM 87545

R. A. Neff

Monsanto Research Corp.

Mound Laboratory

P. O. Box 32

Miamisburg, $\mathrm{OH} 45342$

D. R. Nelson

Office of Safety Policy

\& Standards

ER-8

Department of Energy

Washington, DC 20545

N. S. Nelson

Office of Radiation Programs

(ANR-461)

Environmental Protection

Agency

401 M Street, SW

Washington, DC 20460

P. Nettesheim

National Institutes of

Environmental Health

Sciences

Research Triangle Park, NC 27711 
PNL-7600, Pt. 5

UC-407

W. R. Ney, Executive Director

National Council on Radiation

Protection and

Measurements

7910 Woodmont Avenue

Suite 1016

Washington, DC 20014

M. J. O'Brien

Radiation Safety Office, GS-05

University of Washington

Seattle, WA 98195

D. P. O'Neil

Argonne National Laboratory

9700 South Cass Avenue

Argonne, IL 60439

W. S. Osburn, Jr.

ER-75, GTN

Department of Energy

Washington, DC 20545

R. F. Pelletier

Office of Environmental

Guidance

Department of Energy

Washington, DC 20545

H. J. Pettengill

Office of Health

$\mathrm{EH}-40$

Department of Energy

Washington, DC 20545
A. A. Pitrolo
Morgantown Energy Research
Center
Department of Energy
P. O. Box 880
Morgantown, WV 26505
H. Pulley
Martin Marietta
P. O. Box 1410
Paducah, KY 42001

D. P. Rall, Director
National Institutes of
Environmental Health
Sciences

P. O. Box 12233

Research Triangle Park,

NC 27709

W. C. Reinig

Savannah River Laboratory

E. I. duPont de Nemours \&

Company

Aiken, SC 29808

B. L. Rich

EG\&G Idaho

P. O. Box 1625

Idaho Falls, ID 83415

A. Richardson

Environmental Protection

Agency

401 M Street, SW (ANR-460)

Washington, DC 20460

C. R. Richmond

Oak Ridge National Laboratory

$4500 N, M S-62523$

P. O. Box 2008

Oak Ridge, TN 37831-6253

P. L. Roberson

Radiological Physics

Department

Providence Hospital

Southfield, MI 48037

J. S. Robertson

ER-73, GTN

Department of Energy

Washington, DC 20545

D. M. Rohrer

Office of Health

$\mathrm{EH}-40$

Department of Energy

Washington, DC 20545
S. L. Rose

ER-73, GTN

Department of Energy

Washington, DC 20545

R. D. Rosen, Tech. Librarian

Environmental Measurements Laboratory

Department of Energy

376 Hudson Street

New York, NY 10014

G. J. Rotariu

4609 Woodfield Road

Bethesda, MD 20814

G. Runkle, Chief

Department of Energy, AL

$\mathrm{HPB} / \mathrm{EHD}$

P. O. Box 5400

Albuquerque, NM 87115

L. Sagan

Electric Power Research

Institute

3412 Hillview Avenue

P. O. Box 10412

Palo Alto, CA 94304

R. A. Scarano

Mill Licensing Section

Nuclear Regulatory Commission

Washington, DC 20545

R. E. Schafer

Morgantown Energy Research

Center

Department of Energy

P. O. Box 880

Morgantown, WV 26507-0880

M. Schulman

ER-70, GTN

Department of Energy

Washington, DC 20545 


\author{
D. L. Sheppard \\ EH-121, GTN \\ Department of Energy \\ Germantown, MD 20545 \\ P. H. Silverman \\ Lawrence Berkeley Laboratory \\ Bldg. 50A/5104 \\ Berkeley, CA 94720 \\ W. J. Silvey \\ PE-2, FORS \\ Department of Energy \\ Washington, DC 20585 \\ C. S. Sims \\ Oak Ridge National Laboratory \\ $X-10$, Building 7710, Room 101 \\ P. O. Box 2008 \\ Oak Ridge, TN 37831-6379 \\ W. K. Sinclair, President \\ National Council on Radiation \\ Protection \\ 7910 Woodmont Avenue \\ Suite 1016 \\ Bethesda, MD 20814 \\ D. H. Slade \\ ER-74, GTN \\ Department of Energy \\ Washington, DC 20545 \\ D. A. Smith \\ ER-72, GTN \\ Department of Energy \\ Washington, DC 20545 \\ J. Snow \\ ER-6, FORS \\ Department of Energy \\ Washington, DC 20585 \\ R. G. Stafford \\ Los Alamos National \\ Laboratory \\ MS E584 \\ P. O. Box 1663 \\ Los Alamos, NM 87545
}

J. N. Stannard

University of California

17441 Plaza Animado \#132

San Diego, CA 92128

E. T. Still

Kerr-McGee Corporation

P. O. Box 25861

Oklahoma City, OK 73125

J. N. Swanks

Oak Ridge National Laboratory

MS-6103

P. O. Box 2008

Oak Ridge, TN 37931-6103

J. Swinebroad

Office of Health

EH-40

Department of Energy

Washington, DC 20545

K. Taimi

Office of Environmental

Compliance

$\mathrm{EH}-22$

Department of Energy

Washington, DC 20545

Technical Information Service

Savannah River Laboratory

Room 773A

E. I. duPont de Nemours \&

Company

Aiken, SC 29801

J. G. Themelis

DOE - Albuquerque Operations Office

P. O. Box 5400

Albuquerque, NM 87115

R. H. Thomas, Head

Occupational Health Division,

Bldg. 50A-5104

Lawrence Berkeley Laboratory

University of California

Berkeley, CA 94720
W. T. Thorton

Occupational Safety Branch

P. O. Box A

Aiken, SC 29801

R. E. Toohey

Health Physics Department

Argonne National Laboratory

9700 South Cass Avenue

Argonne, IL 60439

F. Tooper

Operational Standards \&

Analysis Division

Office of Safety Policy \&

Standards

Department of Energy

Washington, DC 20545

A. N. Tschaeche

WINCO

MS 5209

P. O. Box 4000

Idaho Falls, ID 83403

J. C. Tseng

$\mathrm{EH}-35$,

Trevion II

Department of Energy

Washington, DC 20585-0002

T. E. Tuccinardi

Office of Health

$\mathrm{EH}-40$

Department of Energy

Washington, DC 20545

E. J. Vallario

15228 Red Clover Drive

Rockville, MD 20853

B. Valett

NORCUS

390 Hanford Street

Richland, WA 99352 
PNL-7600, Pt. 5

UC-407

F. G. VanLoocke

RMI Company

P. O. Box 579

Ashtabula, $\mathrm{OH} 44004$

C. R. Vest

Battelle, Pacific Northwest

Laboratories

Washington Operations

370 L'Enfant Promenade,

Suite 900

901 D Street, SW

Washington, DC 20024

J. C. Villforth

Food \& Drug Administration

Bureau of Radiological Health

Rockville, MD 20852

G. J. Vodapivc

DOE - Schenectady Naval

Reactors Office

P. O. Box 1069

Schenectady, NY 12301

G. L. Voelz

Los Alamos National

Laboratory

MS-K404

P. O. Box 1663

Los Alamos, NM 87545

B. W. Wachholz

Radiation Effects Branch

National Cancer Institute

EPN, Room 530

8000 Rockville Pike

Bethesda, MD 20892

E. R. Wagner

Portsmouth Gaseous Diffusion

Plant

Martin Marietta Energy

Systems

P. O. Box 628

Piketon, $\mathrm{OH} 45661$
R. A. Walters

Assistant to the Associate

Director

Los Alamos National

Laboratory

MS-A114

P. O. Box 1663

Los Alamos, NM 87545

G. Warren

Stanford Linear Accelerator

P. O. Box 4349

Stanford, CA 94305

W. W. Weyzen

Electric Power Research

Institute

3412 Hillview Avenue

P. O. Box 10412

Palo Alto, CA 94303

H. D. Whitehead

Oak Ridge Gaseous Diffusion Plant

P. O. Box P

Oak Ridge, TN 37831

E. R. Williams

Department of Energy

1000 Independence Ave. SW

Washington, DC 20585

G. A. Wiltsee, Director

Univ. of North Dakota Energy

Research Center

Box 8213, Univ. Station

Grand Forks, ND 58202

F. E. Witmer

EH-131, GTN

Department of Energy

Washington, DC 20545

F. J. Wobber

Department of Energy

14 Goshen Court

Gaithersburg, MD 20879-4403
R. W. Wood

PTRD, OHER

ER-74, GTN

Department of Energy

Washington, DC 20545

M. E. Wrenn

Environmental Radiation \&

Toxicology Laboratory

956 West Levoy, Suite 100

Salt Lake City, UT 84123

Zhu Zhixian

Laboratory for Energy-Related

Health Research

University of California

Davis, CA 95616

FOREIGN

G. E. Adams, Director

Medical Research Council

Radiobiology Unit

Harwell, Didcot

Oxon OX11 ORD

ENGLAND

D. C. Aumann

Institut für Physikalische

Chemie

Universität Bonn

Abt. Nuklearchemie

Wegelerstraße 12

5300 Bonn 1

FEDERAL REPUBLIC OF

GERMANY

M. R. Balakrishnan, Head

Library \& Information Services

Bhabha Atomic Research

Centre

Bombay-400 085

INDIA 
PNL-7600, Pt. 5

UC-407

\author{
J. K. Basson, Vice-President \\ Raad Op Atomic \\ Atoomkrag Energy Board \\ Privaatsk $\times 256$ \\ Pretoria 0001 \\ REPUBLIC OF SOUTH AFRICA

\section{A. M. Beau, Librarian \\ Département de Protection \\ Sanitaire \\ Commissariat à l'Énergie \\ Atomique \\ BP 6 \\ F-92265 Fontenay-aux-Roses \\ FRANCE}

G. Bengtsson, Director-General

Statens Stralskyddsinstitut

Box 60204

S-104 01 Stockholm

SWEDEN

D. J. Beninson

Gerencía de Protección

Radiológica y Seguridad

Comisión Nacional de Energía

Atómica

Avenida del Libertador 8250

$2^{\circ}$ Piso Of. 2330

1429 Buenos Aires

ARGENTINA

A. Bianco

ENEA, Dipart. Protezione

Via le Regina Margherita 125

I-00198 Roma

ITALY

J. Booz

KFA Jülich Institut für Medezin Kernsforschungsanlage Jülich

Postfach 1913

D-5170 Jülich

FEDERAL REPUBLIC OF GERMANY
M. Calamosia

ENEA-LAB Fisica $\mathrm{E}$

Tossicologia Aerosol

Via Mazzini 2

I-40138 Bologna

ITALY

Cao Shu-Yuan, Deputy Head

Laboratory of Radiation

Medicine

North China Institute of

Radiation Protection

P. O. Box 120

Tai-yuan, Shan-Xi

THE PEOPLE'S REPUBLIC OF

CHINA

M. Carpentier

Commission of the European

Communities

200 rue de la Loi

J-70 6/16

B-1049 Brussels

BELGIUM

Chen Xing-An

Laboratory of Industrial

Hygiene

Ministry of Public Health

2 Xinkang Street

Deshengmenwai, Beijing

THE PEOPLE'S REPUBLIC OF

CHINA

R. Clarke

National Radiological

Protection Board

Harwell, Didcot

Oxon OX11 ORQ

ENGLAND

Commission of the European

Communities

DG XII - Library SDM8 R1

200 rue de la Loi

B-1049 Brussels

BELGIUM
Deng Zhicheng

North China Institute of

Radiation Protection

Tai-yuan, Shan-Xi

THE PEOPLE'S REPUBLIC OF

CHINA

Director

Commissariat à l'Énergie

Atomique

Centre d'Etudes Nucléaires

Fontenay-aux-Roses (Seine)

FRANCE

Director

Commonwealth Scientific and Industrial Research

Organization

Aspendal, Victoria

AUSTRALIA

Director

Laboratorio di Radiobiologia

Animale

Centro di Studi Nucleari

Della Casaccia

Comitate Nazionale per

l'Energia Nucleare

Casella Postale 2400

I-00100 Roma

ITALY

D. Djuric

Institute of Occupational and

Radiological Health

11000 Beograd

Deligradoka 29

YUGOSLAVIA.

L. Feinendegen, Director

Institut für Medezin

Kernsforschungsanlage Jülich

Postfach 1913

D-5170 Jülich

FEDERAL REPUBLIC OF

GERMANY 
PNL-7600, Pt. 5

UC-407

M. Fitoussi

Département de Protection

Sanitaire

Commissariat à l'Énergie

Atomique

BP 6

F-92265 Fontenay-aux-Roses

FRANCE

A. Geertsema

Sasol Technology (Pty), Ltd.

P. O. Box 1

Sasolburg 9570

REPUBLIC OF SOUTH AFRICA

G. B. Gerber

Radiobiology Department

Commission of the European

Communities

200 rue de la Loi

B-1049 Brussels

BELGIUM

\section{A. R. Gopal-Ayengar \\ 73-Mysore Colony \\ Mahul Road, Chembur \\ Bombay-400 074 \\ INDIA}

R. V. Griffith

International Atomic Energy

Agency

Wagramerstraße 5

P. O. Box 200

A-1400 Vienna

AUSTRIA

J. L. Head

Department of Nuclear Science \& Technology

Royal Naval College,

Greenwich

London SE10 9NN

ENGLAND
W. W. Hofmann

Division of Biophysics

University of Salzburg Austria

Hellbrunner Str 34

A.5020 Salzburg

AUSTRIA

W. Jacobi

Institut für Strahlenschutz

Ingolstadter Landstraße 1

D-8042 Neuherberg

FEDERAL REPUBLIC OF

GERMANY

K. E. Lennart Johansson

Radiofysiska Inst.

Regionsjukhuset

S-901-82 Umeå

SWEDEN

T. Kivikas

Studsvik Nuclear

S-611 82 Nyköping

SWEDEN

H. J. Klimisch

BASF Aktiengesellschaft

Abteilung Toxikologie, Z470

D-6700 Ludwigshafen

FEDERAL REPUBLIC OF

GERMANY

T. Kumatori

National Institute of

Radiological Sciences

9-1, Anagawa-4-chome

Chiba-shi 260

JAPAN

R. F. Laitano

ENEA - CRE Casaccia

Casella Postale 2400

I-00100 Roma

ITALY
J. R. A. Lakey, Consultant

5 Pine Rise

Meopham, Gravesend

Kent DA13 OJA

ENGLAND

Li De-Ping

Professor and Director of North China Institute of Radiation Protection, NMI

Tai-yuan, Shan-Xi

THE PEOPLE'S REPUBLIC OF CHINA

Librarian

Centre d'Etudes

Nucléaires de Saclay

P. O. Box 2, Saclay

Fig-sur-Yvette (S\&O)

FRANCE

Librarian

CSIRO

314 Albert Street

P. O. Box 89

East Melbourne, Victoria

AUSTRALIA

Librarian

CSIRO

Div. of Atmospheric Research

Station Street

Aspendal, Victoria 3195

AUSTRALIA

Librarian

Kernforschungzentrum

Karlsruhe

Institut für Strahlenbiologie

Postfach 3640

D-75 Karlsruhe 1

FEDERAL REPUBLIC OF

GERMANY 
PNL-7600, Pt. 5

UC-407

\begin{tabular}{|c|c|c|}
\hline Librarian & B Lindell & 」 C Nénot Deputy Director \\
\hline Max-Planck-Institut für & National Institute of Radiation & Département de Protection \\
\hline Biophysics & Protection & Centre d'Etudes Nucléaires \\
\hline Forstkasstraße & Fack S-104 01 & $\mathrm{BP} 6$ \\
\hline D-6000 Frankfurt/Main & Stockholm 60 & F-92260 Fontenay-aux-Roses \\
\hline FEDERAL REPUBLIC OF & SWEDEN & FRANCE \\
\hline & Ma Fubang, Director & R. Osborne \\
\hline Librarian & Chief Engineer & Atomic Energy Commission of \\
\hline Ministry of Agriculture, & Institute of Atomic Energy & Canada, Ltd. \\
\hline Fisheries \& Food & P. O. Box 275 & Biology and Health Physics \\
\hline Fisheries Laboratory & Beijing & Division \\
\hline Lowestoft, Suffolk NR33 OHT & THE PEOPLE'S REPUBLIC OF & Chalk River Nuclear \\
\hline ENGLAND & CHINA & $\begin{array}{l}\text { Laboratories } \\
\text { P. O. Box } 62\end{array}$ \\
\hline Librarian & A. M. Marko & Chalk River, Ontario KOJ $1 \mathrm{JO}$ \\
\hline $\begin{array}{l}\text { National Institute of } \\
\text { Radiological Sciences }\end{array}$ & $\begin{array}{l}9 \text { Huron Street } \\
\text { Deep River, Ontario KOJ } 1 \mathrm{PO}\end{array}$ & CANADA \\
\hline 9-1, Anagawa-4-chome & CANADA & Pan Zi-Qiang \\
\hline Chiba-shi 260 & & Bureau of Safety, Protection \\
\hline JAPAN & $\begin{array}{l}\text { S. Mattsson } \\
\text { Department of radiation Physics }\end{array}$ & $\begin{array}{l}\text { and Health Ministry of } \\
\text { Nuclear Industry }\end{array}$ \\
\hline Library & Malmö General Hopsital & P. O. Box 2102 \\
\hline Alberta Environmental Centre & S-214 01 MALMÖ & Beijing \\
\hline Bag 4000 & SWEDEN & THE PEOPLE'S REPUBLIC OF \\
\hline Vegreville, Alberta & & CHINA \\
\hline TOB 4LO & H. Matsudaira, & \\
\hline CANADA & Director-General & H. G. Paretzke \\
\hline & National Institute of & GSF Institut für Strahlenschutz \\
\hline Library & Radiological Sciences & Ingolstadter Landstraße 1 \\
\hline $\begin{array}{l}\text { Atomic Energy Commission } \\
\text { of Canada, Ltd. }\end{array}$ & $\begin{array}{l}\text { 9-1, Anagawa-4-chome } \\
\text { Chiba-shi } 260\end{array}$ & $\begin{array}{l}\text { D-8042 Neuherberg } \\
\text { FEDERAL REPUBLIC OF }\end{array}$ \\
\hline $\begin{array}{l}\text { Whiteshell Nuclear Research } \\
\text { Establishment }\end{array}$ & JAPAN & GERMANY \\
\hline Pinawa, Manitoba ROE 1LO & O. Matsuoka & N. Parmentier \\
\hline CANADA & Abiko Laboratory & Département de Protection \\
\hline & Central Research Institute & Sanitaire \\
\hline Library & of Electric Power Industry & Centre d'Etudes Nucléaires \\
\hline Department of Meteorology & 1646, Abiko, Abikosi & $\mathrm{BP} 6$ \\
\hline University of Stockholm & Chiba-ken $\quad 270-11$ & F-92260 Fontenay-aux-Roses \\
\hline Arrhenius Laboratory & JAPAN & FRANCE \\
\hline S-106 91 Stockholm & & \\
\hline SWEDEN & R. G. C. McElroy & O. Pavlovski \\
\hline & Atomic Energy Commission of & Institute of Biophysics \\
\hline & Canada, Ltd. & Ministry of Public Health \\
\hline & Dosimetric Research Branch & Givopisnaya 46 \\
\hline & Chalk River, Ontario KOJ 1JO & Moscow D-182 \\
\hline & CANADA & USSR \\
\hline
\end{tabular}


PNL-7600, Pt. 5

UC-407

\section{Prodi \\ Department of Physics \\ University of Bologna \\ Via Irnerio 46 \\ I-40126 Bologna \\ ITALY}

Reports Librarian

Harwell Laboratory, Bldg. 465

UKAEA

Harwell, Didcot

Oxon OX11 ORB

ENGLAND

\section{P. J. A. Rombout \\ Inhalation Toxicology \\ Department \\ National Institute of Public \\ Health and Environmental \\ Protection \\ P. O. Box 1 \\ NL-3720 BA Bilthoven}

THE NETHERLANDS

Professor Rotondi

National Committee of Nuclear

Energy (CNEN)

Casaccia Centre for Nuclear

Studies (CSN)

Casella Postale 2400

I-00100 Roma

ITALY

M. Rzekiecki

Commissariat à l'Énergie

Atomique

Centre d'Etudes

Nucleaires de Cadarache

BP 13-St. Paul

Les Durance

FRANCE

H. Smith

International Commission on

Radiological Protection

P. O. Box 35

Didcot

Oxon OX11 ORJ

ENGLAND
J. W. Stather

National Radiological

Protection Board

Building 383

Chilton, Didcot

Oxon OX11 ORQ

ENGLAND

Sun Shi-quan, Head

Radiation-Medicine Department

North China Institute of Radiation Protection, MNI

P. O. Box 120

Tai-yuan, Shan-Xi

THE PEOPLE'S REPUBLIC OF CHINA

J. W. Thiessen

Radiation Effects

Research Foundation

5-2 Hijiyama Park

Minami-Ku

Hiroshima 732

JAPAN

D. Van As

Atomic Energy Corporation

P. O. Box 582

Pretoria 0001

REPUBLIC OF SOUTH AFRICA

Vienna International Centre Library

Gifts and Exchange

P. O. Box 100

A-1400 Vienna

AUSTRIA

Wang Hengde

North China Institute of

Radiation Protection

P. O. Box 120

Tai-yuan, Shan-Xi

THE PEOPLE'S REPUBLIC OF

CHINA
Wang Ruifa, Associate Director

Laboratory of Industrial

Hygiene

Ministry of Public Health

2 Xinkang Street

P. O. Box 8018

Deshengmenwai, Beijing

100088

THE PEOPLE'S REPUBLIC OF CHINA

Wang Yibing

North China Institute of

Radiation Protection

P. O. Box 120

Tai-yuan, Shan-Xi

THE PEOPLE'S REPUBLIC OF

CHINA

Wei Lü-Xin

Laboratory of Industrial

Hygiene

Ministry of Public Health

2 Xinkang Street

Deshengmenwai, Beijing 100088

THE PEOPLE'S REPUBLIC OF

CHINA

B. C. Winkler

Director, Licensing

Raad Op Atomic

Atoomkrag Energy Board

Privaatsk X 256

Pretoria 0001

REPUBLIC OF SOUTH AFRICA

Wu De-Chang

Institute of Radiation Medicine

27\# Tai Ping Road

Beijing

THE PEOPLE'S REPUBLIC OF

CHINA 
Xie Zi, Senior Engineer

Scientific Secretary of

Radiation Protection Laboratory

Institute of Atomic Energy

P. O. Box 275

Beijing

PEOPLE'S REPUBLIC OF

CHINA

\section{ONSITE}

\section{DOE Richland Operations \\ Office (11)}

D. T. Evans A5-55

E. S. Goldberg A7-50

R. D. lzatt A6-95

P. W. Kruger A5-90

M. W. Tiernan A5-55

G. R. Yesberger (5) A5-55

Public Reading Room A1-65

\section{Tri-Cities University Center}

J. Cooper, Librarian H2-52

Hanford Environmental Health

Foundation (3)

L. J. Maas B2-75

R. Ronish $\mathrm{H} 1-02$

M. J. Swint H1-02

Westinghouse Hanford Co. (4)

R. E. Lerch B2-35

H. E. McGuire B2-35

R. M. Mitchell H4-55

J. E. Nolan B3-01

Pacific Northwest Laboratory (189)

R. C. Adams K6-52

R. W. Baalman K1-50

J. F. Bagley K1-45

W. J. Bair (15) K1-50

D. A. Baker K3-54

E. G. Baker K2-12
C. M. Berkowitz K6-08

D. E. Bihl A3-60

G. R. Bilyard K6-55

L. W. Brackenbush K3-70

P. E. Bramson (5) K1-33

J. J. Breault P7-01

J. B. Brown K5-22

J. W. Buck K6-03

J. L. Buelt P7-44

B. A. Bushaw K3-57

T. D. Chikalla P7-75

T. T. Claudson B1-40

F. T. Cross K4-16

P. G. Doctor K6-96

D. W. Dragnich K1-46

J. G. Droppo K6-96

J. S. Durham K3-55

R. M. Ecker Sequim

C. E. Elderkin K6-08

G. W. R. Endres K3-55

J. W. Falco K6-78

L. G. Faust (10) K3-53

D. R. Fisher K3-53

J. J. Fix P7-01

D. M. Fleming P7-01

W. C. Forsythe K4-16

D. R. Friedrichs K6-15

C. A. Geffen BWO

G. K. Gerke P7-25

W. A. Glass K4-13

J. A. Glissmeyer K6-83

M. J. Graham K6-80

L. K. Grove K6-86

D. E. Hadlock K3-70

J. M. Hales (5) K6-04

R. Harty K3-57

P. C. Hays K6-86

E. E. Hickey K3-56

D. P. Higby P7-78

K. A. Higley K6-96

D. K. Hilliard (3) K2-12

G. R. Hoenes P7-78

L. A. Holmes K1-06

B. L. Hoopes K6-96

J. R. Houston A3-60

R. E. Jaquish K6-13

J. R. Johnson (10) K3-53

J. F. Keller K6-55

W. E. Kennedy, Jr. K3-54
J. L. Kenoyer P7-01

L. J. Kirby P8-08

M. Knotek K1-48

J. P. Kohlman K6-55

T. L. Kuusinen K6-55

W. W. Laity K2-15

D. A. Lamar P7-41

J. L. Latkovich P8-08

J. A. Leonowich P7-03

J. D. Longstreth BWO

M. Lyon A3-60

J. A. MacLellan A3-60

J. B. Martin K3-56

G. A. McAtee K3-18

J. C. McDonald P7-03

J. L. McElroy P7-46

D. A. McNeill K1-06

T. B. Miley K2-32

S. D. Miller K3-57

J. Mishima K6-03

E. B. Moore, Jr. K6-55

R. V. Moraski (5) K6-98

S. M. Nealy (HARC-Pouch)

I. C. Nelson K3-54

R. A. Owens P8-01

H. E. Palmer B1-60

M. A. Parkhurst K3-57

W. T. Pennell K6-98

R. W. Perkins P7-35

J. V. Ramsdell K6-03

L. A. Rathbun P7-01

J. R. Raymond K6-77

W. D. Reece K3-70

J. T. A. Roberts K1-40

R. I. Scherpelz K3-70

R. G. Schreckhise K3-54

W. B. Scott K6-43

J. M. Selby (5) K3-53

R. Shikiar (HARC-Pouch)

B. D. Shipp K1-73

M. R. Sikov P7-50

D. R. Simpson BWO

D. R. Sisk K3-55

J. K. Soldat K3-54

K. L. Soldat K3-57

J. V. Stangeland A3-60

P. S. Stansbury K3-53

R. D. Stenner K3-54

J. G. Stephan K3-56 
PNL-7600, Pt. 5

UC-407

G. A. Stoetzel K3-56

G. M. Stokes K1-74

J. A. Stottlemyre K6-78

J. L. Straalsund K2-15

D. L. Strenge K3-51

C. M. Stroud K3-53

K. L. Swinth K3-55

A. S. Tabatabai (5) BWO

J. E. Tanner K3-70

T. S. Tenforde (2) K1-50

R. J. Traub K3-57

L. M. Valdez K6-90

B. E. Vaughan K1-70

M. B. Walter K6-96

G. Whelan K6-96

T. J. Whitaker K2-21

E. J. Wilczynski BWO

R. E. Wildung P7-50

W. R. Wiley K1-46

M. G. Woodruff K6-55

J. D. Zimbrick P7-50

Health Physics Department Library

Life Sciences Library (2)

Publishing Coordination

Technical Report Files (5) 